\title{
Centennial to millennial climate variability in the far northwestern Pacific (off Kamchatka) and its linkage to the East Asian monsoon and North Atlantic from the Last Glacial Maximum to the early Holocene
}

\author{
Sergey A. Gorbarenko ${ }^{1}$, Xuefa Shi ${ }^{2,3}$, Galina Yu. Malakhova ${ }^{4}$, Aleksandr A. Bosin ${ }^{1}$, Jianjun Zou ${ }^{2,3}$, Yanguang Liu ${ }^{2,3}$, \\ and Min-Te Chen ${ }^{5}$ \\ ${ }^{1}$ V.I. Il'ichev Pacific Oceanological Institute, Vladivostok, Russia \\ ${ }^{2}$ Key Laboratory of Marine Sedimentology and Environmental Geology, First Institute of Oceanography, SOA, \\ Qingdao, China \\ ${ }^{3}$ Laboratory for Marine Geology, Qingdao National Laboratory for Marine Science and Technology, \\ Qingdao, China \\ ${ }^{4}$ North-East Interdisciplinary Science Research Institute FEB RAS, Magadan, Russia \\ ${ }^{5}$ National Taiwan Ocean University, Keelung, Taiwan \\ Correspondence to: Sergey A. Gorbarenko (gorbarenko@poi.dvo.ru)
}

Received: 7 October 2016 - Discussion started: 1 November 2016

Revised: 30 June 2017 - Accepted: 18 July 2017 - Published: 30 August 2017

\begin{abstract}
High-resolution reconstructions based on productivity proxies and magnetic properties of core LV63-412 (off Kamchatka) reveal prevailing centennial productivity/climate variability in the northwestern (NW) Pacific from the Last Glacial Maximum (LGM) to the early Holocene (EH). The age model of the core is established by AMS ${ }^{14} \mathrm{C}$ dating and by projections of AMS ${ }^{14} \mathrm{C}$ data of the nearby core SO-201-12KL through correlation of the productivity proxies and relative paleomagnetic intensity. The resulting sequence of centennial productivity increases/climate warming events in the NW Pacific occurred synchronously with the East Asian summer monsoon (EASM) sub-interstadials during the LGM (four events), Heinrich Event 1 (HE1) (four events), Bølling-Allerød (B/A) warming (four events), and over the $\mathrm{EH}$ (four events). Remarkable similarity of the sequence of the NW Pacific increased-productivity events with the EASM sub-interstadials over the LGM-HE1 implies that the Siberian High is a strong and common driver. The comparison with the $\delta^{18} \mathrm{O}$ record from Antarctica suggests that another mechanism associated with the temperature gradient in the Southern Hemisphere may also be responsible for the EASM/NW Pacific centennial events over the LGMHE1. During the B/A warming and resumption of the At-
\end{abstract}

lantic Meridional Overturning Circulation (AMOC), clear synchronicity between the NW Pacific, EASM and Greenland sub-interstadials was mainly controlled by changes in the atmospheric circulation. During the EH the linkages between solar forcing, ocean circulation, and climate changes likely control the synchronicity of abrupt climate changes in the NW Pacific and North Atlantic. The sequence of centennial events recorded in this study is a persistent regional feature during the LGM-EH, which may serve as a template in high-resolution paleoceanography and sediment stratigraphy in the NW Pacific.

\section{Introduction}

Model simulations and proxy-based records have both led to contradictory results on the millennial-scale environmental variability in the northwestern (NW) Pacific and its underlying mechanisms during the last deglaciation. These model and proxy studies suggested either in-phase relationships of deglacial variability between the North (N) Atlantic and NW Pacific (Caissie et al., 2010; Chikamoto et al., 2012; Kienast and McKay, 2001; Seki et al., 2002) or out-of-phase 
responses (Gebhardt et al., 2008; Sarnthein et al., 2006). The in-phase relationship has been attributed to rapid atmospheric teleconnections in the Northern Hemisphere on a decadal timescale (Max et al., 2012). The winter Arctic Oscillation (AO), which resembles the North Atlantic Oscillation, directly influences the surface air temperature and sea level pressure over the region northwards of $35^{\circ} \mathrm{N}$ in East Asia (Sung et al., 2006). The Siberian High (SH), an essential component of northern East Asian atmosphere system, significantly influences the East Asian winter monsoon (EAWM) (Wu and Wang, 2002), which in turn affects the environment of NW Pacific. When winter $\mathrm{AO}$ is in its positive phase, both the winter SH and EAWM are weaker than their normal state and the air temperature of the surface to middle troposphere is higher than normal (Wu and Wang, 2002), which ameliorate the NW Pacific environment. The out-ofphase response, however, was proposed to be driven by a seesaw mechanism, with oceanic readjustments between the weakening of the Atlantic Meridional Overturning Circulation (AMOC) and the strengthening of the Pacific Meridional Overturning Circulation (Okazaki et al., 2010).

Records of $\delta^{18} \mathrm{O}$ from the Greenland ice cores revealed the Dansgaard-Oeschger (DO) millennial-scale oscillations (interstadials and stadials) during the last glaciation (Dansgaard et al., 1993; Johnsen et al., 1992) and similar millennial-scale events have also been identified in a number of terrestrial and marine records in other regions. For example, a synthesis of the last glacial pollen records from the European continent provides evidence that the warmer intervals in Europe correspond to millennial-scale interstadials in Greenland (Fletcher et al., 2010). Sediment cores from the N Pacific and its marginal seas have also shown abrupt, millennial-scale climate and environment ameliorations, similar to interstadials in Greenland ice cores during the last glaciation. Records of $\delta^{18} \mathrm{O}$ of planktic foraminifera (Kennett et al., 2000) and alkenone-derived sea surface temperature (SST) (Seki et al., 2002) from the northeastern (NE) Pacific also exhibited millennial climate oscillations very similar in magnitude with DO cycles over the last glaciation. INTIMATE stratigraphy studies introduced the subdivision of the GI-1 into subinterstadials GI-1a to GI-1e. Furthermore, the GS-2.1 was subdivided into sub-stadials GS-2.1a (during Heinrich Event 1, HE1), GS-2.1b (Last Glacial Maximum, LGM), and GS2.1c (Björck et al., 1998; Rasmussen et al., 2014). The sequence of abrupt warming and environmental ameliorations similar to DO interstadials in Greenland were also interpreted by using alkenone-derived SST (Harada et al., 2008) and geochemical, diatom and pollen data (Gorbarenko et al., 2004) in sediment cores investigated from the Okhotsk Sea. The Bering Sea was also characterized by climate and environmental oscillations corresponding to DO cycles based on productivity proxies, sediment density, opal content and micropaleontological records (Gorbarenko et al., 2005; Kim et al., 2011; Riethdorf et al., 2013; Schlung et al., 2013).
By comparing the dust content in the North Greenland Ice Core Project (NGRIP) ice core with that of the dust record in a sediment core from the subarctic N Pacific, Serno et al. (2015) demonstrated synchronicity of millennial-scale changes in atmospheric circulation between the N Pacific and the Greenland during the last $27 \mathrm{kyr}$ (Serno et al., 2015). Previous studies also found the occurrence of increased export of productivity during the period of millennial-scale climate and environmental ameliorations, correlated with DO interstadials, in the Okhotsk and Bering seas (Gorbarenko et al., 2005; Kim et al., 2011; Riethdorf et al., 2013; Seki et al., 2004).

Recent studies on high-resolution and well-dated sediment cores from the subarctic NW Pacific, the Okhotsk Sea, and the western Bering Sea show the variations in SST during the last deglaciation similar to the NE Pacific and to the N Atlantic and Greenland temperature variability (Caissie et al., 2010; Max et al., 2012; Seki et al., 2002). These studies suggest a close linkage to deglacial variations in AMOC associated with rapid atmospheric teleconnection, which were responsible for a quasi-synchronous SST pattern between the $\mathrm{N}$ Atlantic and N Pacific during the last deglaciation. Furthermore, a recent study by Praetorius and Mix (2014), based on multi-decadal-resolution foraminiferal $\delta^{18} \mathrm{O}$ records from the Gulf of Alaska, revealed a synchronicity of rapid climate shifts between the N Atlantic/Greenland (NGRIP record) and the NE Pacific between 15.5 and $11 \mathrm{ka}$. During the Holocene and HE1, inverse relationships between the N Atlantic and the N Pacific are suggested by Praetorius and Mix (2014), while the short-term variability is either not sufficiently resolved or decoupled. A lack of high-resolution records in the NW Pacific prohibits a precise assessment of any possible climatic teleconnection between the $\mathrm{N}$ Pacific and $\mathrm{N}$ Atlantic.

Besides centennial-millennial oscillations reported during the last glacial periods, centennial precipitation anomalies from LGM to the Holocene have also been reported in cave stalagmite $\delta^{18} \mathrm{O}$ records of the East Asian monsoon (Dykoski et al., 2005; Wang et al., 2001, 2005, 2008; Yuan et al., 2004). Furthermore, the timing and pattern of variability during the early Holocene $(\mathrm{EH})$ regional climate changes are still under debate. In particular, though the EH climate has started from a strong warming in most cases, a Hani peat $\delta^{18} \mathrm{O}$ record from NE China instead suggest a centennial cooling event which is primarily superimposed on a long-term warming trend during the Holocene (Hong et al., 2009).

Here we present high-resolution results of productivity proxies, sediment magnetic properties, and lithological composition of a sediment core LV 63-41-2 (hereinafter 41-2) (off Kamchatka) from the NW Pacific. Our records reveal a sequence of centennial productivity/climate variability from 20 to $8 \mathrm{ka}$. An age model of core 41-2 was constructed using accelerator mass spectrometry (AMS) ${ }^{14} \mathrm{C}$ dating and by correlating the productivity events and relative paleomagnetic intensity (RPI) variability with those of the well-dated nearby 


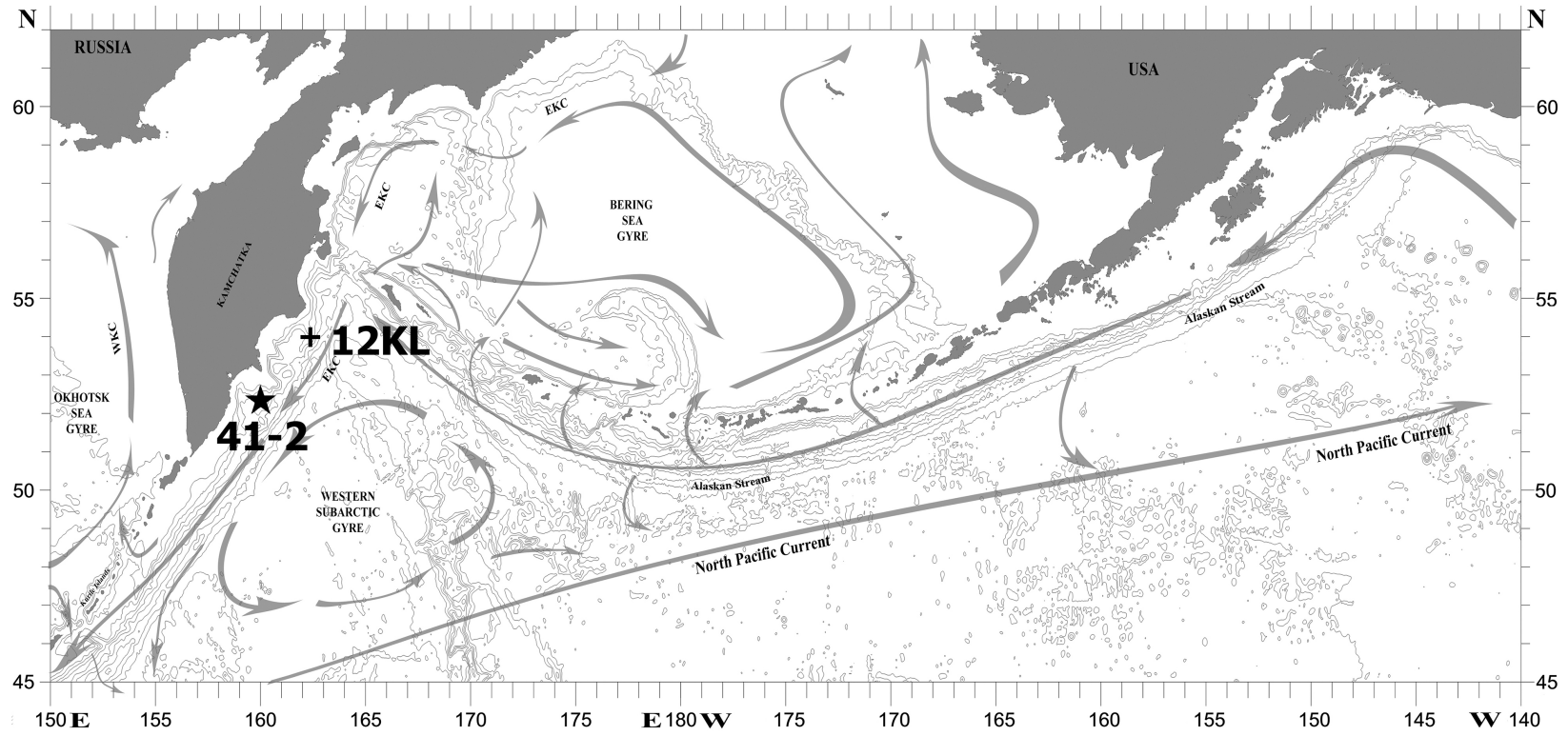

Figure 1. Bathymetry, surface water currents and location of the cores 41-2 (star) and 12KL (cross) (Max et al., 2012) in the N Pacific. Surface currents as in Favorite et al. (1976) with modifications. EKC - East Kamchatka Current; WKC - West Kamchatka Current.

core SO-201-12KL (hereinafter 12KL) (Max et al., 2012, 2014). Using robust age controls, we establish a tight linkage between the centennial events with higher productivity in the NW Pacific and the sub-interstadial strengthened East Asian summer monsoon (EASM) expressed in cave stalagmite $\delta^{18} \mathrm{O}$ records. These results enable further investigation of any mechanisms controlling the in-phase relationships of the centennial variability in the NW Pacific/EASM and those underlying the Greenland/N Atlantic and Antarctic climate changes during the LGM through EH.

\section{Materials and methods}

Sediment core $41-2\left(52^{\circ} 34^{\prime} \mathrm{N}, 160^{\circ} 01^{\prime} \mathrm{E}\right.$; water depth: $1924 \mathrm{~m}$ ) was recovered from the NW Pacific off the Kamchatka Peninsula during the Russian-Chinese joint expedition on R/V Akademik M.A. Lavrentyev in 2013. The length of the core is $467 \mathrm{~cm}$. In order to establish the age model of core 41-2, we also analyzed paramagnetic magnetization and chlorin content in core $12 \mathrm{KL}\left(53^{\circ} 59^{\prime} \mathrm{N}, 162^{\circ} 23^{\prime} \mathrm{E}\right)$, which has been dated well by Max et al. (2012, 2014) (Fig. 1).

\subsection{Coarse fraction}

Terrigenous materials are mainly transported by sea ice in the studied region and therefore the coarse fraction $(\mathrm{CF})$ and magnetic susceptibility (MS) of sediments (Gorbarenko et al., 2003, 2012; Lisitzin, 2002; Sakamoto et al., 2005) can be used as a proxy for ice-rafted debris (IRD). Semi-quantitative estimates of terrigenous and volcanic particles (tephra) in the $\mathrm{CF}$ allow the determination of core intervals with insignificant amounts of tephra, and therefore intervals with impli- cations for CF and MS as an IRD index. Semi-quantitative estimates of major components in the sediment $\mathrm{CF}$, including terrigenous and volcanic particles, benthic and planktic foraminifera shells, diatom frustules, and radiolarian skeletons on a 12-point scale, were made by using a microscope for roughly estimating the proportions of different components in the sediment (Rothwell, 1989).

The weight percentage of the CF $(63-2000 \mu \mathrm{m})$ was obtained at $1 \mathrm{~cm}$ interval after wet sieving the sediment and calculated as a ratio of CF weight to the total weight of dry bulk sediment.

\subsection{Chlorin}

Chlorin content is assumed to reflect changes in primary surface ocean productivity because continental-derived chlorophyll contributes insignificantly to its composition in deep marine sediment (Harris et al., 1996). The chlorin content in core 41-2 was measured by a Shimadzu UV-1650PC spectrophotometer at $1 \mathrm{~cm}$ resolution, and at $2 \mathrm{~cm}$ resolution in core $12 \mathrm{KL}$, using the same analytical reagents and pretreatment procedures proposed by Harris et al. (1996).

\subsection{Total organic carbon (TOC), calcium carbonate $\left(\mathrm{CaCO}_{3}\right)$, and color b*}

Contents of TOC, $\mathrm{CaCO}_{3}$, and biogenic opal in deep-sea sediments are usually used as key parameters to assess paleoproductivity (Berger et al., 1989; Narita et al., 2002; Prahl et al., 1989; Seki et al., 2004). The color $b^{*}$ values correlate well with the changes in biogenic opal content in sediment cores (Nürnberg and Tiedemann, 2004) and are widely used as a 
paleoproductivity proxy in the NW Pacific and its marginal seas (Gorbarenko et al., 2012; Max et al., 2012; Riethdorf et al., 2013).

Total carbon and inorganic carbon contents in core 41-2 were measured at every $2 \mathrm{~cm}$ throughout the core by coulometry using an AN-7529 analyzer in the same way, which has been reported by Gorbarenko et al. (1998). TOC content was determined by calculating the difference between total carbon and inorganic carbon content. Color $\mathrm{b}^{*}$ index (psychometric yellow-blue chromaticness) was measured with $1 \mathrm{~cm}$ resolution using a Minolta CM-2002 color reflectance spectrophotometer (Harada, 2006).

\subsection{Radiocarbon dating (AMS ${ }^{14} \mathrm{C}$ )}

AMS ${ }^{14} \mathrm{C}$ ages were measured in monospecific samples of the planktic foraminifera Neogloboquadrina pachyderma sinistral ( $N$. pachyderma sin.) from the $125-250 \mu \mathrm{m}$ fraction, and benthic foraminifera Epistominella pacifica, and Uvigerina parvocostata from the $250-350 \mu \mathrm{m}$ fraction of the core. The radiocarbon dating was performed by John Southon at the Keck Carbon Cycle AMS Facility (UCIAMS) in the Earth System Science Department of the University of California, USA.

The constant reservoir age $(900 \pm 250$ years $)$ of the NW Pacific surface water (Max et al., 2012) was adopted in this study to convert the ${ }^{14} \mathrm{C}$ data into calendar ages by using Calib Rev 6.0 (Stuiver and Reimer, 1993) with the Marine13 calibration curve (Reimer et al., 2013) to establish consistent AMS ${ }^{14} \mathrm{C}$ chronologies between cores $41-2$ and $12 \mathrm{KL}$. When using benthic foraminifera for AMS ${ }^{14} \mathrm{C}$ dating on the cores, an age difference of 1400 years is taken between coexisting benthic and planktic foraminifera ages (Max et al., 2014).

\subsection{Magnetic properties}

Variations in the Earth's magnetic field, recorded by RPI, present an independent chronological instrument of marine and continental sediments (Channell et al., 2009) and are widely used for sediment correlation and chronology determination (Kiefer et al., 2001; Riethdorf et al., 2013). The sediment paramagnetic magnetization (PM) was formed in marine sediments in the open NW Pacific by silicate, paramagnetic iron sulfide (FeS), and fine clay minerals, the main part of which was transported from land as an eolian dust through atmospheric circulation by westerly jets (Serno et al., 2015). Therefore, the sediment PM may serve as a proxy for the land aridity and atmosphere circulation pattern changes. The volume MS of sediments was mainly formed by ferromagnetic minerals delivered together with terrigenous materials from adjacent land by sea ice, which is the main transport agent of clastic materials into the NW Pacific and its marginal seas (Gorbarenko et al., 2003; Lisitzin, 2002; Sakamoto et al., 2005).
The sediment magnetic properties were measured at $2.2 \mathrm{~cm}$ resolution in cores $41-2$ and 12KL. MS of these samples was measured by an AGICO MFK1-FA device. The characteristic of remanent magnetization (ChRM) of the samples was measured in the same way by studying the stability of natural remanent magnetization (NRM) in alternative magnetic fields of up to $80-100 \mathrm{mT}$ on the basis of analysis of Zijderveld vector plots, using an AGICO LDA3Adevice and rock generator AGICO JR-5a (Zijderveld, 1964). The module and direction of NRM were measured on a JR-5A rock generator after the stepwise demagnetization of reference samples by alternating magnetic fields with vanishing amplitude (Malakhov et al., 2009). Anhysteretic remanent magnetization (ARM) was generated using an AGICO AMU-1A device and measured using the JR-5A rock generator. The RPI of the studied core was determined by the normalization of the ChRM after demagnetization at $20 \mathrm{mT}$ by ARM (ChRM/ARM) (Tauxe, 1993). The sediment PM was measured for each sample from curves of magnetic hysteresis by a J Meter coercitive spectrometer at Kazan State University, Kazan, Russia (Enkin et al., 2007; Jasonov et al., 1998).

\subsection{In situ X-ray fluorescence core scanning}

Previous studies have shown that the non-destructive, highresolution X-ray fluorescence (XRF) measurements of biogenic barium, bromine and silica (Ba-bio, Br-bio, and $\mathrm{Si}$ bio, respectively) by a core scanner or synchrotron radiation are consistent with analytically measured contents of Babio, TOC, and biogenic opal, respectively, and therefore may be used as paleoproductivity proxies (Goldberg et al., 2005; Nürnberg and Tiedemann, 2004; Riethdorf et al., 2016). Babio is formed during the decay of organic matter in the water column and the uptake of Ba in settling particles (Dymond et al., 1992), and has been previously used as a proxy of productivity (Goldberg and Arrhenius, 1958; McManus et al., 1998). Si-bio, related to biogenic opal in deep-sea sediments, is usually used as a key parameter to assess paleoproductivity (Berger et al., 1989; Narita et al., 2002; Seki et al., 2004). Brbio content measured using a core scanner is strongly correlated with TOC variability (Riethdorf et al., 2013) and therefore may also be used as a paleoproductivity proxy.

The elemental composition of core 41-2 was measured as peak area in counts per second at $0.5 \mathrm{~cm}$ resolution using the Itrax XRF core scanner at the First Institute of Oceanography, State Oceanic Administration, China. The Itrax XRF core scanner was set at $20 \mathrm{~s}$ count times, $30 \mathrm{kV}$ X-ray voltage, and an X-ray current of $20 \mathrm{~mA}$. Though absolute elemental concentrations are not directly available from the micro-XRF measurements, the count values can be used as estimates of the relative concentrations. The count values may be influenced by changes in the physical properties of the sediment, such as the water content and surface roughness of the core (Röhl and Abrams, 2000). However, the grain size of the 41- 
Table 1. AMS ${ }^{14} \mathrm{C}$ data in monospecies planktic foraminifera $N$. pachyderma sin. and benthic foraminifera Epistominella pacifica and Uvigerina parvocostata of core 41-2. All measured AMS ${ }^{14} \mathrm{C}$ data were calibrated by Calib 6.0 (Stuiver and Reimer, 1993) with Marine13 calibration curve (Reimer et al., 2013) with a surface water reservoir ages of 900 years (Max et al., 2014). In the case of using benthic foraminifera for dating, we accept that the difference in paired benthic-planktic foraminifera ages equals 1400 years, based on unpublished data and total regional results of Max et al. (2014). All radiocarbon ages were converted into calibrated $1 \sigma$ calendar age.

\begin{tabular}{llrlrrr}
\hline No. Lab. code & $\begin{array}{r}\text { Core depth } \\
\mathrm{cm}\end{array}$ & $\begin{array}{l}\text { Foraminifera } \\
\text { species }\end{array}$ & $\begin{array}{r}{ }^{14} \mathrm{C} \text { age } \\
\text { year }\end{array}$ & $\begin{array}{r}\text { Err. } 1 \sigma \\
\text { year }\end{array}$ & $\begin{array}{r}\text { Calendar } \\
\text { age, ka }\end{array}$ \\
\hline 1 & YAUT-021713 & 120 & E. pacifica & 10078 & 47 & 9.121 \\
2 & YAUT-021714 & 127.5 & E. pacifica & 10340 & 42 & 9.445 \\
3 & UCIAMS-148095 & 298 & N.pachyd. & 13160 & 50 & 14.393 \\
4 & UCIAMS-148096 & 156 & Uv. parvoc. & 11135 & 45 & 10.60 \\
5 & UCIAMS-148098 & 306 & Uv. parvoc. & 14185 & 35 & 14.616 \\
\hline
\end{tabular}

2 core is rather fine and the surface has been processed to be as flat as possible to minimize any effects from changing physical properties or roughness during the scanning.

In this study, attention was paid to the XRF scanning results for estimating the productivity proxies such as Ba-bio, Br-bio and Si-bio contents in our sediment core. The content of Ba-bio was estimated by the subtraction of its terrigenous component from the total Ba concentration in sediment (Ba-tot). The terrigenous component was, in turn, calculated from empirical regional $(\mathrm{Ba} / \mathrm{Al})_{\text {ter }}$ ratios in the sediment core with the lowest Ba-tot contents multiplied by relative $\mathrm{Al}$ content:

Ba-bio $=$ Ba-tot $-(\mathrm{Ba} / \mathrm{Al})_{\text {ter }} \cdot \mathrm{Al}$ (Goldberg et al., 2005).

The contents of Br-bio and Si-bio were calculated in the same way.

\section{Results}

\subsection{Productivity events}

Down-core variability in all productivity proxies (color $\mathrm{b}^{*}$ and contents of TOC, chlorin, $\mathrm{CaCO}_{3}$, Ba-bio, Si-bio, and Br-bio) in core 41-2 is presented in Fig. 2. Taking the available AMS ${ }^{14} \mathrm{C}$ data into account (Table 1), the middle part of the core (the interval $\sim 315-230 \mathrm{~cm}$ ) with increased contents/values of all productivity proxies could be chronologically assigned to the Bølling-Allerød (B/A) warming right after the late last glaciation $(467-315 \mathrm{~cm})$. A decreased trend of productivity records at the interval of $\sim 230-190 \mathrm{~cm}$ is likely associated with the YD cooling and the subsequent high productivity trend in the upper $190 \mathrm{~cm}$ is presumably related to the Holocene warming (Fig. 2). We interpret that the climate became warmer in the NW Pacific during the B/A period, terminating the last glaciation, then it reversed to the cooling during the Younger Dryas (YD) followed by the significant warming throughout the Holocene. This climate sequence has been well documented by the $\delta^{18} \mathrm{O}$ records of the Greenland ice cores and climate records from the N Atlantic (Bond et al., 2001; Dansgaard et al., 1993; Johnsen et al., 1992; Stuiver et al., 1995), by classical sequence of European pollen zone (Nilsson, 1983) and by well-dated pollen biome records of southern Siberia (Bezrukova et al., 2010; Tarasov et al., 2009). The abovementioned patterns of climate variability during the LGM-EH in moderate-high latitudes of the Northern Hemisphere is consistent with the $\mathrm{N}$ Pacific and its marginal seas, evidenced by the alkenone- derived SST (Barron et al., 2003; Max et al., 2012) and pollen records (Gorbarenko et al., 2003, 2004). The significant increase in productivity in the NW Pacific during the B/A was likely achieved by additional nutrient input into the euphotic layer due to accelerated sea level rise (Siddall et al., 2010) accompanied by the supply of organic matter from the submerged shelf and by prolonged blooming season due to the warming, which is a common paleoceanography feature of the N Pacific and its marginal seas (Barron et al., 2003, 2009; Caissie et al., 2010; Galbraith et al., 2007; Gorbarenko, 1996; Gorbarenko et al., 2005; Gorbarenko and Goldberg, 2005; Keigwin, 1998; Keigwin et al., 1992; Max et al., 2012; Seki et al., 2004).

In core 41-2, the temporal resolutions of measured color $\mathrm{b}^{*}$ and chlorin are nearly 30 years; $\mathrm{TOC}, \mathrm{CaCO}_{3}$ and magnetic parameters (PM, MS, and RPI) are nearly 60 years; and Ba-bio, Br-bio, and Si-bio are nearly 15 years. The resolution is high enough to allow us to detect the centennial-scale productivity variability in the NW Pacific. However, not all productivity proxies change synchronously (Fig. 2).

Each productivity proxy has its own specific limitations and peculiarities in response to the environmental and primary productivity changes. For example, carbonaceous fossils (planktic foraminifera and coccolithophorids) rain from the euphotic layer, exported by primary production, and they provide the main carbonate input into the sediment. However, the $\mathrm{CaCO}_{3}$ content in the deep-sea sediment is also governed by climatically forced variability in the deep water chemistry and carbonate ion concentration $\left(\mathrm{CO}_{3}^{2-}\right)$, resulting in different carbonate preservation in the past (Yu et al., 2013). As for the Ba-bio proxy, Jaccard et al. (2010) suggest that in the highly productive areas, barite dissolution has 


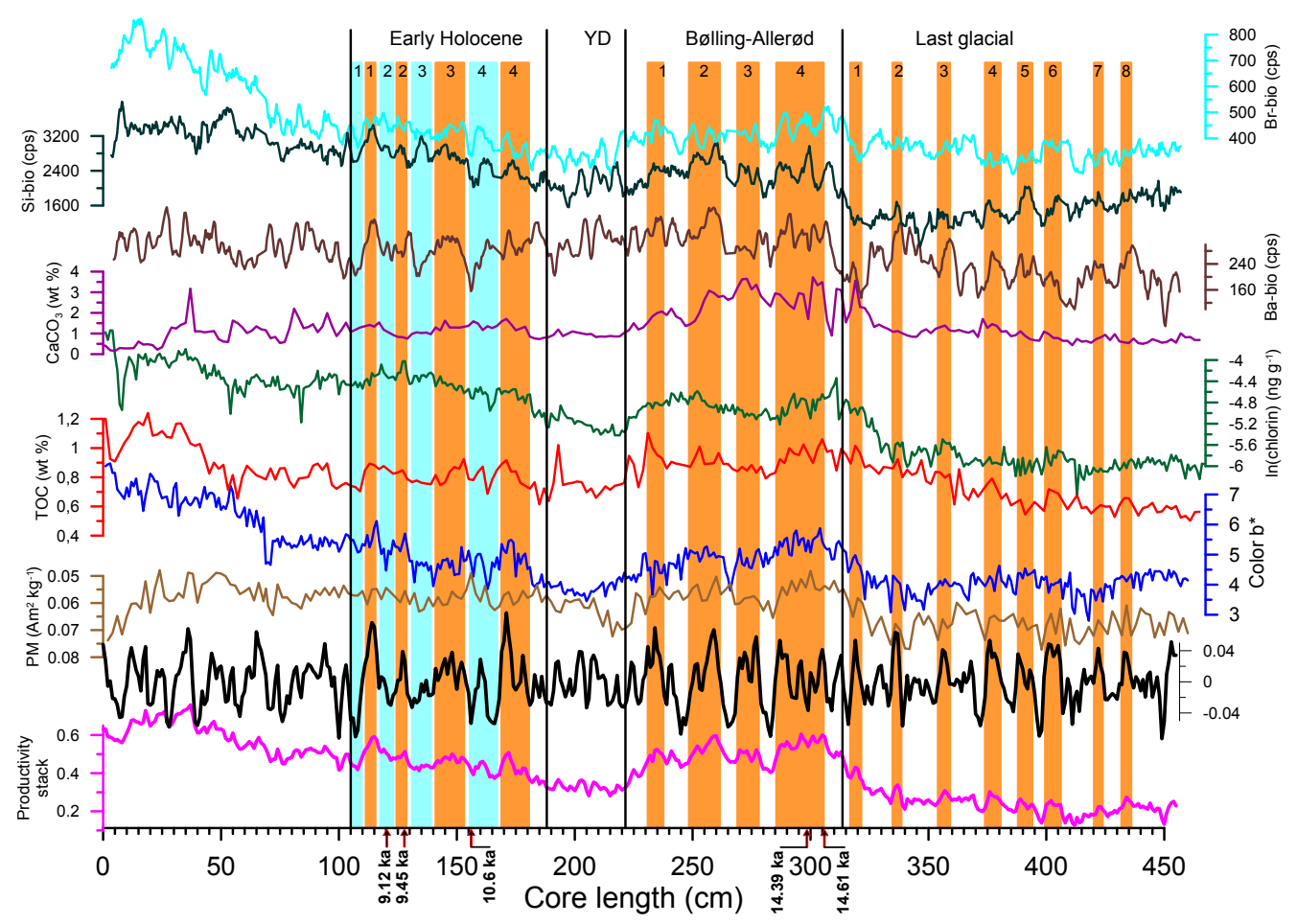

Figure 2. Records (from bottom to top) of the original and detrended productivity stacks, $\mathrm{PM}$, color $\mathrm{b}^{*}, \mathrm{TOC}, \mathrm{chlorin}, \mathrm{CaCO} 3, \mathrm{Ba}$-bio, Si-bio, and Br-bio versus depth. Preliminary boundaries of the B/A warming, YD cooling, and Holocene are shown according to general variability in productivity in the NW Pacific, Sea of Okhotsk, and Bering Sea (Galbraith et al., 2007; Gorbarenko, 1996; Gorbarenko and Goldberg, 2005; Keigwin, 1998; Seki et al., 2004). AMS ${ }^{14} \mathrm{C}$ data (calendar ka) are shown at the base. Blue bars indicate cold periods/lowerproductivity events. Orange bars indicate warm periods/high productivity events.

been observed under suboxic conditions, precluding its application as a quantitative proxy to reconstruct past changes in export production. Although it has been suggested that biogenic opal is responsible for the accumulation of siliceous fossils, while TOC is responsible for siliceous plus carbonaceous fossils with other organic remains (Berger et al., 1989), they vary in different ways at various periods in sediments of the NW Pacific and its marginal seas. For example, biogenic opal content in the Okhotsk Sea significantly lags the TOC changes during the last deglaciation-Late Holocene interval (Gorbarenko et al., 1998; Seki et al., 2004). TOC content in the hemipelagic sediment includes the organic carbon formed by marine primary production, and the terrigenous organic material delivered from land. Although it was suggested that color $b^{*}$ values correlate well with the changes in biogenic opal content in sediment cores (Nürnberg and Tiedemann, 2004), the measured color $b^{*}$ values in core $41-2$ do not change synchronously with Si-bio content in the entire length of the core (Fig. 2). The presentation of a wide range of productivity records allows us to evaluate the discrepancy among proxies. In addition, the combination of proxies provides a more reliable way for evaluating the productivity changes.
For the statistical assessment of the centennial productivity variability, a stack of productivity proxies is calculated. It is an average of the normalized data of each proxy with equal weight (Fig. 2). Data from the productivity stack were detrended by subtracting long-term periodicity that allow us to determine the sequence of centennial productivity events with higher productivity throughout the studied core and events with lower productivity during the $\mathrm{EH}$ based on the seven productivity proxies measured (Fig. 2). The calculated productivity stack has high negative correlation with PM of sediments $(r=-0.63)$. This indicates that centennial events with increased productivity occurred during weakening of dust delivery and deposition in the NW Pacific by atmospheric circulation associated with abrupt climate warming. Such causal linkages between centennial productivity increases and abrupt climate warming in the NW Pacific are also consistent with millennial-scale productivity/climate oscillations during the DO interstadials found in the Okhotsk and Bering Seas (Gorbarenko et al., 2005; Kim et al., 2011; Riethdorf et al., 2013; Seki et al., 2004). As a result, the records of different productivity proxies and the detrended productivity stack show eight short-term events with higher productivity occurred during the LGM and HE1 and four events during the $\mathrm{B} / \mathrm{A}$ warming. During the $\mathrm{EH}$, produc- 
tivity records show four events of lower and higher productivity, respectively (Fig. 2).

It is noted that a low-productivity event at $\sim 9.1 \mathrm{ka}$ (Table 1) is well correlated with the $9.3 \mathrm{ka}$ cold event recorded in NGRIP (Rasmussen et al., 2014). Moreover, a lowproductivity event identified at depth of $105-110 \mathrm{~cm}$ also correspond to the 8.2 ka cold event, a well-known chronostratigraphic marker in the early to middle Holocene boundary (Walker et al., 2012).

\subsection{Age model}

The RPI, productivity stack and PM of core 41-2 were compared with the RPI, several productivity proxies, and PM records of nearby core $12 \mathrm{KL}$ (Fig. 3). The color $\mathrm{b}^{*}$ index and $\mathrm{Ca}$ (analog of $\mathrm{CaCO}_{3}$ content) of core $12 \mathrm{KL}$ were obtained from Max et al. (2012, 2014). The correlation of the centennial productivity events between cores was provided by comparison of productivity stack of core 41-2 with productivity proxies of core $12 \mathrm{KL}$ and by comparison of the RPI and PM curves. An age model of core 41-2 was constructed using all available $\mathrm{AMS}{ }^{14} \mathrm{C}$ data, with additional age control points identified by correlating the centennial productivity events, RPI and PM of the studied core with those of the well-dated adjacent core 12KL (Max et al., 2012, 2014) (Fig. 3). The age tuning used in this study assumes a synchronous pattern of productivity, RPI and PM variability in the NW Pacific since the last glacial, especially for closely located cores. Therefore, the centennial variability in productivity proxies with increased-productivity events, RPI of Earth's magnetic field, and PM identified in cores $41-2$ and $12 \mathrm{KL}$ have to be closely matched in both cores over the last glaciation-B/A warming to the EH (Fig. 3). It was noted that the available age model for core 12KL (the Tiedemann/Max age model) (Max et al., 2012 , 2014) was based on the AMS ${ }^{14} \mathrm{C}$ data and correlation of color $\mathrm{b}^{*}$ index with the NGRIP $\delta^{18} \mathrm{O}$ curve. For adopting this age model to Core $41-2$, the AMS ${ }^{14} \mathrm{C}$ data of core $12 \mathrm{KL}$ were projected to Core 41-2 according to the correlation of related productivity events, RPI and PM (Fig. 3). The color $\mathrm{b}^{*}$ minimum in core $12 \mathrm{KL}$ at a depth of $706 \mathrm{~cm}$, which correlates with a minimum in the NGRIP $\delta^{18} \mathrm{O}$ record at $16.16 \mathrm{ka}$, is also clearly correlated with the color $\mathrm{b}^{*}$ minimum in core 41-2 at a depth of $348 \mathrm{~cm}$ (Fig. 3). All correlated AMS ${ }^{14} \mathrm{C}$ data points are also well matched with the measured RPI curves of both cores (Fig. 3). Our four AMS ${ }^{14} \mathrm{C}$ data are fairly close to the projected ${ }^{14} \mathrm{C}$ data from core $12 \mathrm{KL}$ (Table 3 ) with age differences within $\pm 0.1 \mathrm{kyr}$, confirming the validity of these key point projections. Here the use of ${ }^{14} \mathrm{C}$ data of core $12 \mathrm{KL}$ is preferred, because this core has a higher sedimentation rate, and planktic foraminifera for these measurements were picked up from intervals with higher $\mathrm{Ca}$ peaks, aiming to reduce the effect of bioturbation on the precision of the age model.

A close temporal correlation of these NW Pacific increased-productivity events with sub-interstadials in the
Table 2. Centennial events with increased/decreased productivity during $25-8 \mathrm{ka}$ in core $41-2$ and the average ages according to the correlations between productivity events and the EASM subinterstadials and sub-stadials (CsI/CsS).

\begin{tabular}{lrr}
\hline Events & $\begin{array}{r}\text { Core interval, } \\
\mathrm{cm}\end{array}$ & $\begin{array}{r}\text { Averaged } \\
\text { cal. age, ka }\end{array}$ \\
\hline CsS-EH-1 & $105-110$ & 8.2 \\
CsI-EH-1 & $111-116$ & 8.6 \\
CsS-EH-2 & $117-123$ & 9.1 \\
CsI-EH-2 & $124-129$ & 9.5 \\
CsS-EH-3 & $131-140$ & 9.9 \\
CsI-EH-3 & $141-153$ & 10.5 \\
CsS-EH-4 & $155-167$ & 11.1 \\
CsI-EH-4 & $168-181$ & 11.5 \\
CsI-GI1-a & $231-238$ & 13.1 \\
CsI-GI1-c1 & $248-262$ & 13.5 \\
CsI-GI1-c3 & $269-279$ & 13.8 \\
CsI-GI1-e & $285-306$ & 14.3 \\
CsI-GS2.1-1 & $317-322$ & 14.9 \\
CsI-GS2.1-2 & $335-339$ & 15.5 \\
CsI-GS2.1-3 & $353-360$ & 16.5 \\
CsI-GS2.1-4 & $373-381$ & 17.5 \\
CsI-GS2.1-5 & $388-395$ & 18.1 \\
CsI-GS2.1-6 & $399-407$ & 18.6 \\
CsI-GS2.1-7 & $420-425$ & 19.2 \\
CsI-GS2.1-8 & $432-437$ & 19.5 \\
\hline
\end{tabular}

EASM becomes apparent after projection of the radiocarbon data of both cores on absolute $\mathrm{U}-\mathrm{Th}$-dated $\delta^{18} \mathrm{O}$ record of Chinese cave stalagmites (Wang et al., 2008) during 20-8 ka (Fig. 3). Such inferred synchronicity of abrupt NW Pacific productivity events and EASM sub-interstadials was used for further tuning of the age model. This was achieved by fine tuning of the increased-productivity events with related subinterstadials of $\delta^{18} \mathrm{O}$ Chinese stalagmites at a depth beyond the projected AMS ${ }^{14} \mathrm{C}$ data (Fig. 3; Table 3).

The sequence of centennial events of increased productivity seems to have occurred in phase with decreasing PM in both cores (Fig. 3), indicating a weakening of eolian dust transportation by atmospheric circulation in the study area likely due to climate warming, analogous with millennialscale forcing of dust transportation into the NW Pacific (Serno et al., 2015). Within the constructed age model of core 41-2, different productivity proxies and magnetic records, combined with similar data from core 12KL (Max et al., 2012, 2014) reveal a sequence of noticeable centennial events of increased productivity in the NW Pacific which occurred in phase with Chinese sub-interstadials (CsI) associated with stronger EASM or weaker EAWM (Wang et al., 2008) and changes in atmospheric circulation during 21-8 ka (Figs. 3 and 4).

These linkages suggest that centennial-scale increasedproductivity events in the NW Pacific were likely associated with shifts of a warmer regional climate and/or higher 
(c)

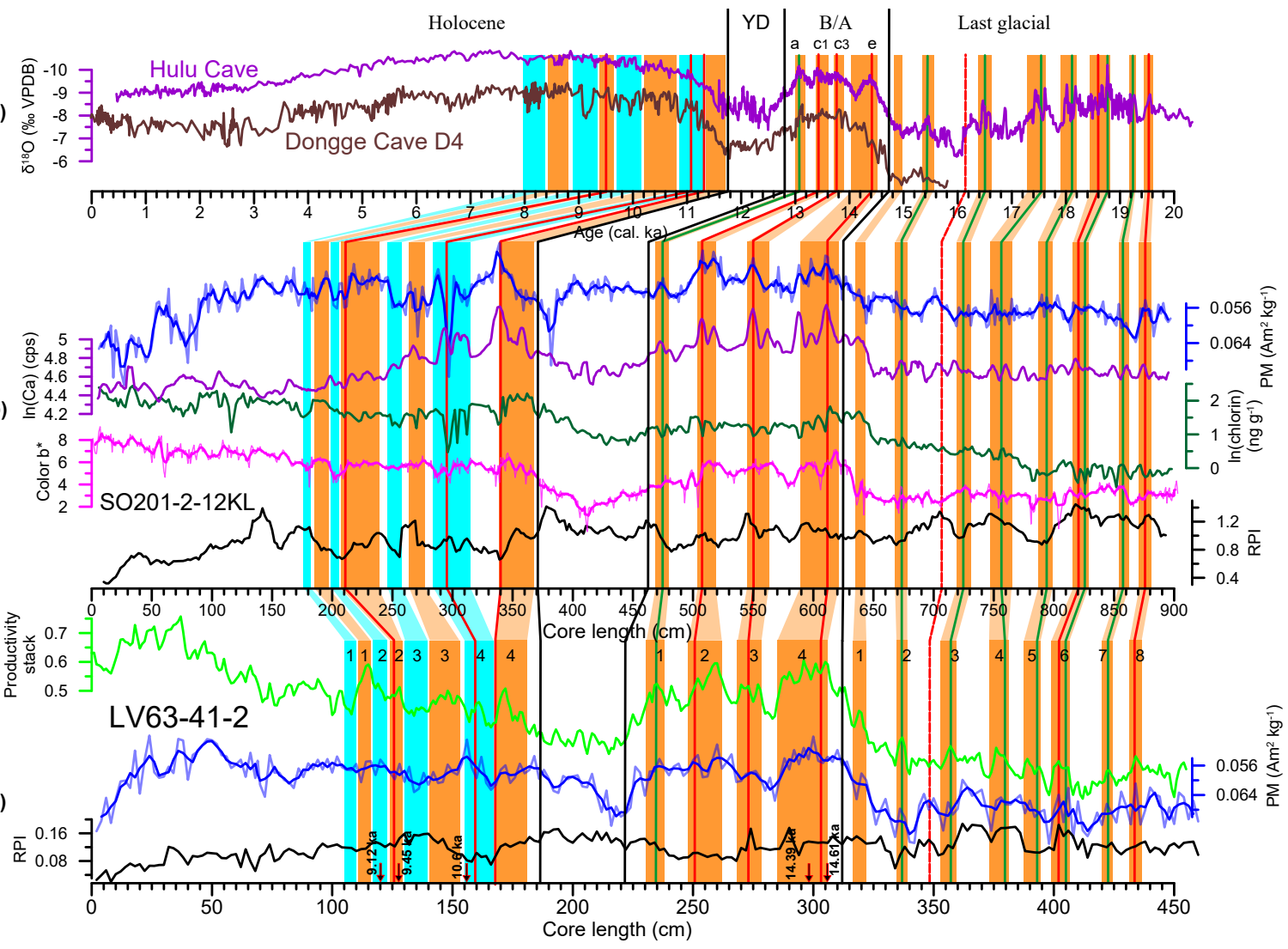

Figure 3. Age model of core 41-2. (a) RPI, PM and productivity stack of core 41-2 versus depth. (b) RPI, color b*, chlorin, Ca and PM of core $12 \mathrm{KL}$ versus depth. (c) $\delta^{18} \mathrm{O}$ calcite of Chinese cave stalagmites (Dykoski et al., 2005; Wang et al., 2008) over the last 20 kyr. The correlation of productivity events between core 41-2 and 12KL was established according to correlation of productivity stack of core 41-2 with productivity proxies of core $12 \mathrm{KL}$ and the RPI records of both cores. AMS ${ }^{14} \mathrm{C}$ data of core $12 \mathrm{KL}$ (red lines) were projected to the core 41-2 according to correlated productivity events. A close correlation of the productivity events with sub-interstadials in the EASM becomes apparent after projection of the radiocarbon data on the age scale of EASM. Green lines correlate EASM sub-interstadials with productivity events. Orange and blue bars are as in Fig. 2.

nutrient availability in surface water, synchronous with CsI of the EASM. According to Wang et al. (2001), the interstadials of EASM are broadly correlated with regional climate warming. High-resolution records presented here show clearly that four centennial-scale events of increased productivity/environmental amelioration correlated with CsI during the LGM, four events during HE1, four events during the B/A warming, and four events during the EH (Fig. 4; Table 2).

\section{Discussion}

\subsection{Productivity patterns during the LGM-HE 1}

Besides the centennial productivity/environmental events, similar NW Pacific productivity patterns are found in cores 41-2 and 12KL during the LGM and HE1 with some differences in different productivity proxies. During the LGM, most proxies demonstrate a minimum primary productivity in the NW Pacific without definite trends (Fig. 4). Severe en- vironmental conditions in central Asia inferred from pollen data (Bezrukova et al., 2010) (Fig. 5) seem to have promoted an increase in winter sea ice formation and sea ice cover in NW Pacific, consistent with high IRD accumulation inferred from $\mathrm{CF}$ and MS records (Fig. 4), which might have inhibited productivity in the study area. It is also consistent with the minimum productivity in the NW Pacific due to strong stratification, preventing the supply of nutrients required to support productivity in surface waters (Gebhardt et al., 2008).

From 17.8 to $15.3 \mathrm{ka}$, the TOC and chlorin contents associated with the production of calcareous phytoplankton (mostly coccolithophores) show a significant increase concurrently with the diminished AMOC (McManus et al., 2004). The diminished AMOC resulted in a major cooling of the Northern Hemisphere and, most likely, reduced water evaporation in the $\mathrm{N}$ Atlantic and therefore Atlantic-Pacific moisture transport (Okazaki et al., 2010). This condition facilitates an overall increase in surface water salinity, and decrease in surface stratification in the N Pacific, promoting 
Table 3. The age controlling points of core $41-2$ derived from available AMS ${ }^{14} \mathrm{C}$ data of core $41-2$, projection of AMS ${ }^{14} \mathrm{C}$ ages of core $12 \mathrm{KL}$, and tie points through correlation between increased-productivity events and EASM CsIs (Wang et al., 2008). One AMS ${ }^{14} \mathrm{C}$ datum of core 12KL at depth of $706 \mathrm{~cm}$ was accepted according to the Tiedemann/Max age model 2 (Max et al., 2012, 2014).

\begin{tabular}{lrrrr}
\hline Depth & $\begin{array}{r}\text { AMS }{ }^{14} \mathrm{C} \\
\text { core } 41-2\end{array}$ & $\begin{array}{r}\text { Key time points } \\
\text { of core 12KL }\end{array}$ & $\begin{array}{r}\text { Correlation with } \\
\text { ages of China } \\
\text { sub-interstadial }\end{array}$ & $\begin{array}{r}\text { Accepted } \\
\text { key time points }\end{array}$ \\
cm & cal. age, ka & ka/depth (cm) & & cal. age, ka \\
\hline 120 & 9.12 & & & 9.12 \\
127.5 & 9.45 & $9.51 / 210$ & & 9.51 \\
126 & & & & \\
156 & 10.6 & $11.08 / 295$ & & 11.08 \\
159 & & $11.31 / 340$ & & 11.31 \\
167 & & & $13.08 /$ GsI-GI1-a & 13.08 \\
234 & & $13.42 / 508$ & & 13.42 \\
251 & & $13.79 / 550$ & & 13.79 \\
273 & & & & \\
298 & 14.39 & $14.42 / 611$ & & 14.42 \\
303 & & & $15.42 /$ CsI-GS2.1-2 & 15.42 \\
306 & 14.61 & & $16.51 /$ CsI-GS2.1-3 & 16.16 \\
337 & & $16.16 / 706$ & 16.51 \\
348 & & & $17.56 /$ CsI-GS2.1-4 & 17.56 \\
357 & & & & 18.12 \\
379 & & & $18.78 /$ CsI-GS2.1-6 & 18.78 \\
393 & & $18.6 / 821$ & & 19.25 \\
402 & & & $19.25 /$ CsI-GS2.1-7 & 19.54 \\
405 & & & & \\
423 & & $19.54 / 876$ & & \\
434 & & & & \\
\hline
\end{tabular}

an intensified ventilation of the intermediate water. The observed trends of productivity proxies are in concord with strong intensification of the intermediate-depth water ventilation in the N Pacific during HE1 (Max et al., 2014). However, fairly constant $\mathrm{CaCO}_{3}$ values in both cores (water depth 1924-2145 m) during the LGM-HE1 do not indicate that the water ventilation penetrated to deep water in the $\mathrm{N}$ Pacific over that time interval because carbonate concentration in the sediment is strongly constrained by the ventilation of bottom water (Yu et al., 2013). The productivity proxies such as Si-bio and color $\mathrm{b}^{*}$, associated with siliceous phytoplankton production (mostly diatoms), were low and do not show significant trends during HE1 up to $\sim 15.3 \mathrm{ka}$ (Figs. 2 and 4). The enhanced coverage of sea ice, shown by CF and MS records (Fig. 4), until $15.3 \mathrm{ka}$ in the studied area probably led to the large spring-early summer surface water stratification which impeded production of diatom. Both CF and MS records may represent IRD changes over the LGM-YD because the input of volcanic materials estimated in CF was insignificant during 21-12 ka compared to that of the Holocene (Fig. 4).

A sharp increase in the NW Pacific primary production, as well as a rise in the diatom production since $\sim 15.3 \mathrm{ka}$ indicated by most productivity proxies and Si-bio and color $\mathrm{b}^{*}$ records with a peak at sub-interstadial GI1-e of B/A warm- ing (Fig. 4), was likely induced by a decreased effect of sea ice and its spring melting, favoring a weakening of surface stratification. The timing of the decrease in the sea ice cover since $\sim 15.3 \mathrm{ka}$ is consistent with the regional surface water warming (Max et al., 2012). Such a pattern in productivity changes in the $\mathrm{N}$ Pacific and the Bering Sea during the glacial-interglacial transitions has been reported in previous studies (Caissie et al., 2010; Galbraith et al., 2007; Gebhardt et al., 2008; Gorbarenko, 1996; Keigwin, 1998) and was likely a persistent feature of the N Pacific and its realm, forced by the resumption of the AMOC at the B/A warming.

\subsection{Centennial variations in productivity during the LGM-HE1-B/A}

The identification of potential linkages between centennial climate changes in the Northern Hemisphere (NW Pacific, EASM, and N Atlantic/Greenland) and the climate changes recorded in the Antarctic ice cores is important for deepening our understanding of the mechanisms responsible for the timing and spatial propagation patterns that resulted from abrupt variability in global climate and environmental system. In order to test these linkages, the centennial productivity/climate events in the NW Pacific outlined by the productivity stack are compared with records from the Northern Hemisphere 


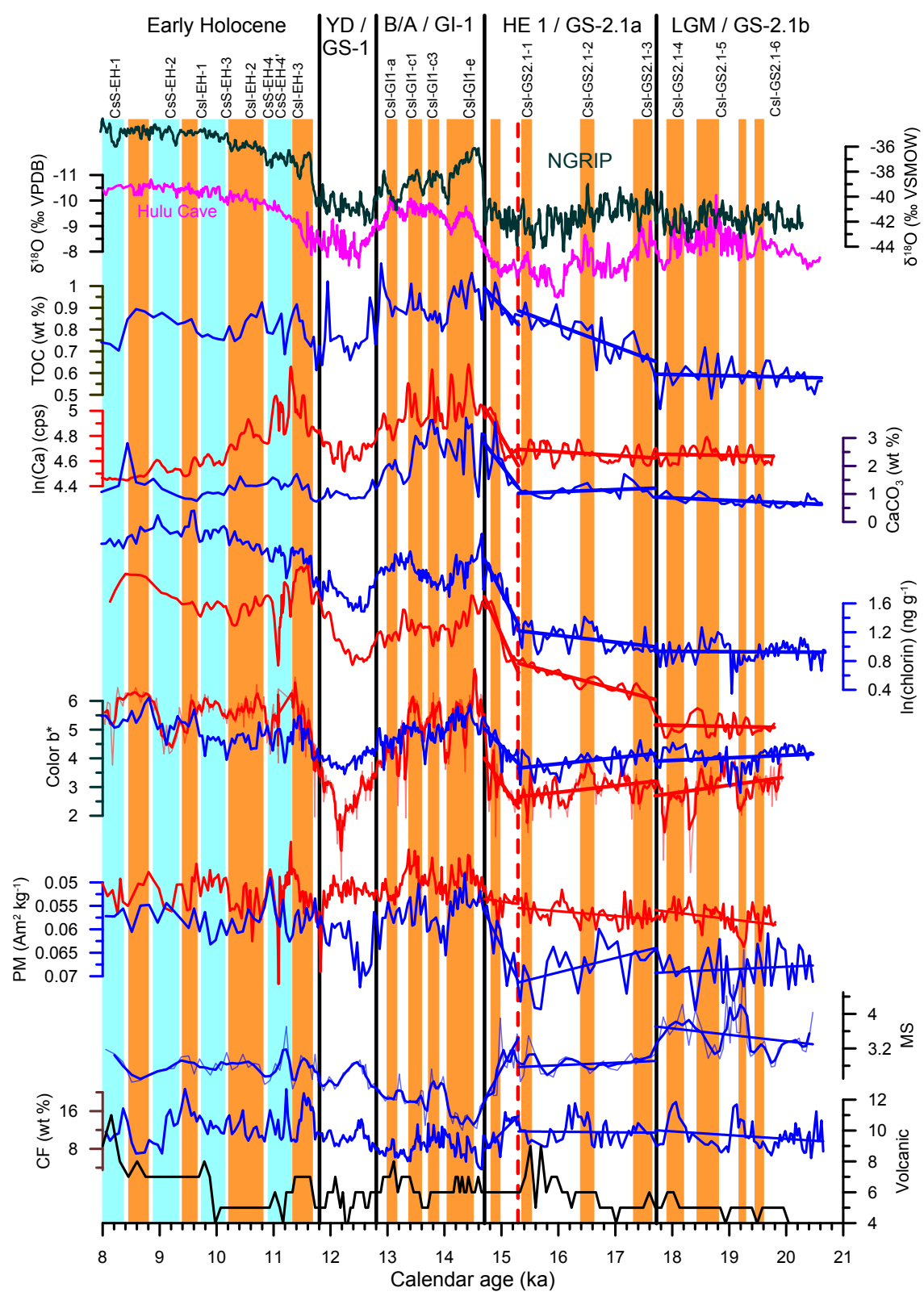

Figure 4. High-resolution variability in the productivity and lithologic proxies in the NW Pacific during 21-8 ka. Volcanic particles, CF, MS, PM, color b*, chlorin, $\mathrm{CaCO}_{3} / \mathrm{Ca}$, and TOC determined in cores 41-2 (blue lines) and $12 \mathrm{KL}$ (red lines) are shown from bottom to top. $\Delta^{18} \mathrm{O}$ records of EASM (Wang et al., 2008) and NGRIP (North Greenland Ice Core Project members, 2004) are shown at the top of the figure. Linear trends are shown for productivity and lithologic proxies during 20-17.8, 17.8-15.3, and 15.3-14.7 ka periods. The red dashed line marks the boundary in productivity and lithologic trends during HE1 at $15.3 \mathrm{ka}$. Orange and blue bars are as in Fig. 2.

$\left(\delta^{18} \mathrm{O}\right.$ and $\mathrm{Ca}^{2+}$ of NGRIP, $\delta^{18} \mathrm{O}$ of EASM, N Atlantic IRD, Siberian climate) and from the Southern Hemisphere (Fig. 5). It has been suggested that the nearly synchronous ice core $\delta^{18} \mathrm{O}$ and $\mathrm{Ca}^{2+}$ millennial-scale changes reflect the shifting of the Greenland atmospheric dust loading, which is closely linked with the atmospheric circulation and climate changes in the high latitudes of the Northern Hemisphere, where the EASM plays an important role (Ruth et al., 2007).
Similarity of glacial millennial-scale climate variability recorded in Chinese cave stalagmites and Greenland ice cores (Sun et al., 2012; Wang et al., 2001) implies a plausible influence of high-latitude climate of the Northern Hemisphere on the EASM by atmospheric circulation changes. Several main elements of atmospheric circulation, including the Intertropical Convergence Zone (ITCZ), northern westerly jet, $\mathrm{AO}$ and the $\mathrm{SH}$, were previously considered as potential mechanisms linking abrupt climate changes in the $\mathrm{N}$ 


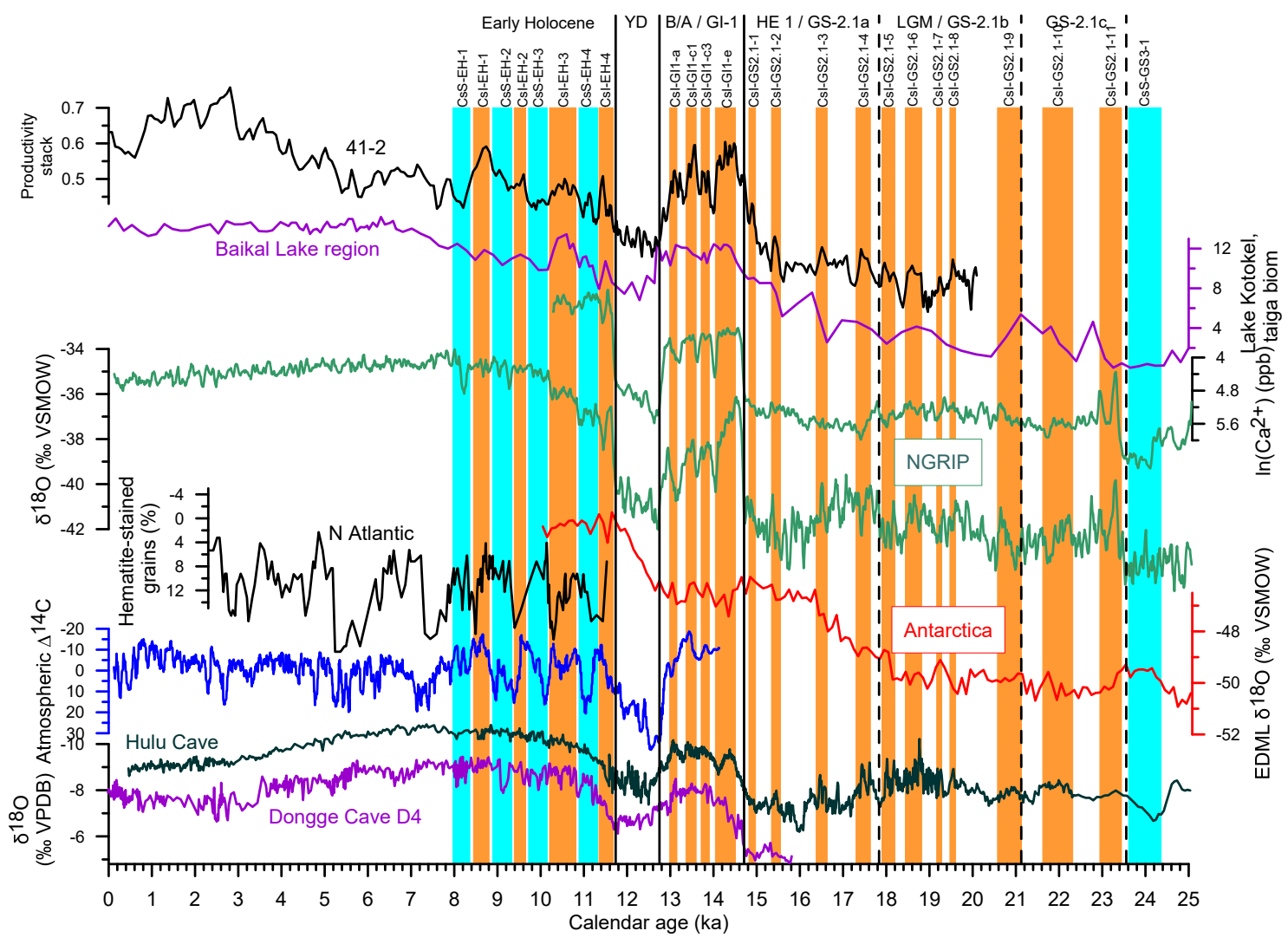

Figure 5. Compilations of Northern and Southern Hemisphere climate records, solar activity, NW Pacific productivity events, and vegetation records from southern Siberia during the last $25 \mathrm{kyr}$. From bottom to top: absolute-dated $\delta^{18} \mathrm{O}$ calcite of Chinese cave stalagmites (Dykoski et al., 2005; Wang et al., 2008), the residual atmospheric $\Delta^{14} \mathrm{C}$ record of around 2000 -year moving average (Reimer et al., 2004), $\delta^{18} \mathrm{O}$ EDML records after methane synchronization with the N Greenland ice core (EPICA Community Members, 2006), the petrologic tracer of drift ice in the $\mathrm{N}$ Atlantic (Bond et al., 2001), the $\delta^{18} \mathrm{O}$ and $\mathrm{Ca}^{2+}$ records in the Greenland NGRIP ice core indicated air temperature and dust variability on GICC05 age scale (Rasmussen et al., 2014), pollen-reconstructed southern Siberia environment changes (Lake Baikal region) (Bezrukova et al., 2010) and productivity stack for core 41-2. Orange and blue bars are as in Fig. 2. Centennial events with increased productivity are associated with sub-interstadial of the EASM and with increasing input of solar irradiance during the LGM-B/A and EH short-term warmings, respectively. The correlation between short-term increased Greenland temperature (NGRIP ice core) and a decreased Antarctic temperature is less pronounced but seems to be marked as well.

Atlantic and East Asia (Jin et al., 2007; Nagashima et al., 2011; Sung et al., 2006; Timmermann et al., 2007).

Apparent similarity of centennial climate and environment variability between the NW Pacific productivity events, EASM and Greenland records (Fig. 5) allows us to suggest that mechanisms responsible for their teleconnection were the same as on millennial scales. The remarkable similarity of the sequence of NW Pacific productivity events with the sub-interstadials of EASM records during the LGMHE1 (Fig. 5) implies a strong common driver. Wu and Wang (2002) concluded that SH has provided direct and significant influence on the EAWM, particularly by sea level pressure and northerly wind along the East Asian coast. Simultaneously, the SH strongly influences the sea ice formation in the NW Pacific and marginal seas by similar mechanisms like the wind intensity controlled by pressure gradient and winter air temperature at sea level (Kimura and Wakat- suchi, 1999). Records of CF and MS, related to IRD accumulation, show that studied area off Kamchatka was influenced by sea ice during the LGM-HE1 (Fig. 4). We propose that the enhancement of SH, associated with abrupt climate cooling, led to an increase in terrigenous material delivery by sea ice from the coast and to a decrease in primary productivity by shrinking of productive season between events with increased productivity.

Correlation of the centennial changes in the NW Pacific productivity events/CsIs with Greenland sub-interstadials during the LGM-HE1 was mainly observed but less clear, due to the discrepancy in constructed age models and/or to possible differences in atmospheric teleconnections (Fig. 5). There are some differences between coeval $\delta^{18} \mathrm{O}$ values in the Summit and NGRIP ice cores during the LGM-HE1, which were likely controlled by changes in the $\mathrm{N}$ American Ice Sheet volume and N Atlantic sea-ice coverage, resulting 
in the meridional discrepancy in the $\delta^{18} \mathrm{O}$ of Greenland ice (Seierstad et al., 2014).

EPICA Community Members (2006) showed that methane synchronization of the EDML and the $\delta^{18} \mathrm{O}$ of NGRIP reveal one-to-one alignment of each Antarctic warming with a corresponding stadial in the Greenland ice cores, implying a bipolar seesaw mechanism on millennial timescales. Since it was shown that Chinese and Greenland interstadials have occurred synchronously (Wang et al., 2001), Chinese interstadials (CIs) were also likely related to the Antarctic cold events. For example, warmer conditions in the Antarctic during 23.6-24.3 ka (coeval with Chinese sub-stadial CsS-GS31) were synchronous with abrupt climate cooling and an increase in dust content in the Greenland ice cores NGRIP, coeval with HE2 of the N Atlantic, and in phase with the weakening of the EASM (GS/CS-3.1) (Fig. 5). The Antarctic cooling after 23.4 ka was accompanied by warming in Greenland, with two sharp interstadials (GI-2.2 and GI-2.1; Rasmussen et al., 2014) and an EASM interstadial (CI-2; Wang et al., 2001) (Fig. 5).

It has also been suggested that an index of monsoon intensity was controlled not only by the Northern Hemisphere temperature ("pull" on the monsoon, which is more intense during boreal warm periods) but also by the pole-to-Equator temperature gradient in the Southern Hemisphere ("push" on the monsoon, which is more intense during the boreal cold periods), which leads to enhanced boreal summer monsoon intensity and its northward propagation (Rohling et al., 2009; Rossignol-Strick, 1985; Xue et al., 2004). Since the EASM transports heat and moisture from the West Pacific Warm Pool (WPWP) to higher latitudes (Wang et al., 2001), the temperature gradient in the Southern Hemisphere "pushes" the northward propagation of EASM via the latitudinal/longitudinal migrations or expansion/contraction of the WPWP (Rohling et al., 2009; Xue et al., 2004). This also explains the difference in responses to the EASM and Greenland interstadials and sub-interstadials, because the migration of the WPWP may have occurred more slowly than the atmospheric circulation changes (Rohling et al., 2009; Xue et al., 2004). The changes in the $\delta^{18} \mathrm{O}$ records of Chinese stalagmites were more gradual than in the $\delta^{18} \mathrm{O}$ records of Greenland ice cores, and were more similar to the changes in Antarctic air temperature (Fig. 5). Therefore, it is possible that forcing from the low-latitude "push effect" on the EASM was an additional mechanism in centennial productivity changes in the NW Pacific due to surface water amelioration. Although the time resolution of the Antarctic $\delta^{18} \mathrm{O}$ curve was not as high as ones from the Greenland and the EASM, records demonstrated in Fig. 5 do not exclude one-to-one alignment of each Antarctic centennial cooling with related EASM sub-interstadial/NW Pacific productivity events.

We suggest that, in addition to the eight centennial productivity/environmental events during the LGM-HE1 established in the studied cores from the NW Pacific, another three abrupt productivity/climate events likely took place in the NW Pacific, synchronous with CsIs outlined by the $\delta^{18} \mathrm{O}$ records of Chinese stalagmites and the Greenland during the interval of 25-20 ka (namely CsI-GS2.1-11, CsI-GS2.1-10, and CsI-GS2.1-9) (Fig. 5).

During the B/A warming and resumption of the AMOC, four sub-interstadials (CsI-GI1-a to CsI-GI1-e) were clearly and simultaneously observed in the Greenland ice cores $\delta^{18} \mathrm{O}$ (Björck et al., 1998) and dust records and EASM sub-interstadials synchronously with centennial productivity/environment events of the NW Pacific (Fig. 5). It is consistent with enhancement of the "pull effect" on the intensified EASM and therefore amelioration of the NW Pacific during boreal warm periods, which implies a dominant control of Northern Hemisphere climate processes on the atmospheric circulation in high latitudes (Rohling et al., 2009). Related significant coeval changes in the atmosphere circulation with periodicity ca. $0.4 \mathrm{ka}$ exert strong influence on the climate and environment in the ocean and continents of the Northern Hemisphere during the B/A (Bezrukova et al., 2010).

\subsection{Centennial variations in productivity during the $\mathrm{EH}$}

During the EH the records presented here show an alternation of the four NW Pacific centennial events with lower productivity and four with higher productivity, namely CsS-EH1-CsS-EH-4 and CsI-EH-1-CsI-EH-4, respectively (Figs. 4 and 5; Table 2). Two low-productivity events (CsS-EH-1 and CsS-EH-2) are likely correlated with Greenland cold events at 8.2 and $9.3 \mathrm{ka}$, respectively (Rasmussen et al., 2014). Also, the NW Pacific low-productivity events (CsSEH-1, CsS-EH-2 and CsS-EH-3) occurred synchronously with the EASM decrease and climate cooling recorded in $\delta^{18} \mathrm{O}$ of the Dongge cave stalagmite D4 (Dykoski et al., 2005) (Fig. 5). Therefore, it may be suggested that, during the EH, the NW Pacific events with higher/lower productivity had occurred coeval with climate warming/cooling as well. The pollen-based reconstruction of the variability in the vegetation/climate from a well-dated core from southern Siberia (Lake Baikal region) (Bezrukova et al., 2010) demonstrated nearly the same pattern of centennial variability during the EH (Fig. 5). Well-dated, high-resolution lithological and geochemical results from the Yanchi Playa (NE China) also clearly showed a sequence of three sharp cooling events at 8.2, 9.9-10.1, and 11.0-11.2 ka (Yu et al., 2006), quasi-synchronous with the NW Pacific productivity/climate events CsS-EH-1, CsS-EH-3 and CsS-EH-4. Yu et al. (2006) explained this correlation through linkages between the tropical Pacific and N Atlantic.

An alternation of the NW Pacific events with lower/higher productivity during the EH demonstrates a perfect correlation with periodicities of solar activity and the production of the cosmogenic nuclides ${ }^{14} \mathrm{C}$ and ${ }^{10} \mathrm{Be}$ (Reimer et al., 2004) (Fig. 5). The production rates of these cosmogenic nu- 


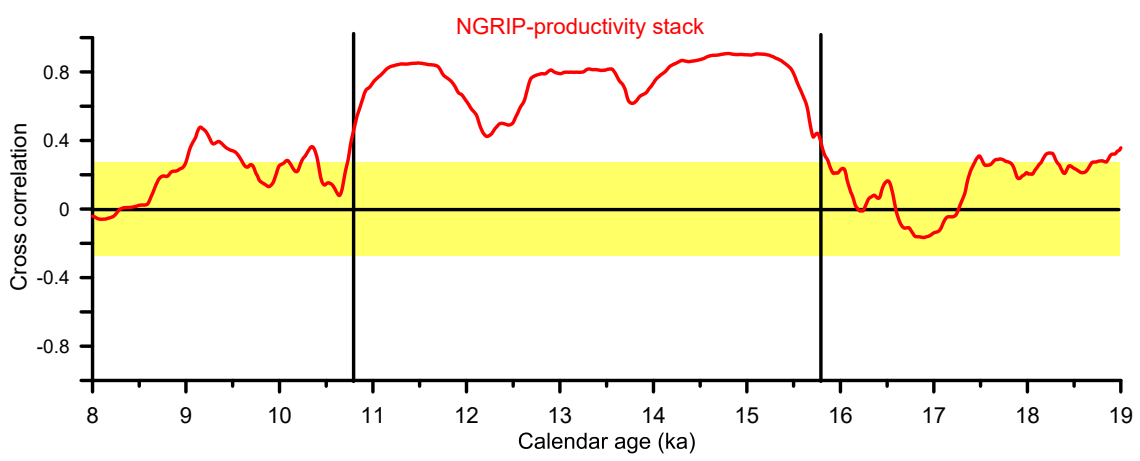

Figure 6. Cross correlation (CC) of the NW Pacific productivity stack and $\delta^{18} \mathrm{O}$ records of the NGRIP (Rasmussen et al., 2014), using moving windows at 2000 years. Yellow bars depict the CC within range \pm 0.25 . Vertical black lines distinguish an interval from 10.8 to $15.8 \mathrm{ka}$ with significant $\mathrm{CC}$ (from -0.6 to -0.9 ) from less significant CC during earlier and later intervals, indicating the synchronicity climate changes between the N Atlantic and NW Pacific.

clides and residual atmospheric $\Delta^{14} \mathrm{C}$ record are negatively correlated with total solar irradiance due to the strength of magnetic fields embedded into the solar wind (Hu et al., 2003). Small variations in solar irradiance could be responsible for pronounced changes in northern high-latitude climate and environments (Bond et al., 2001; Hu et al., 2003). The NW Pacific events of higher productivity occurred during increased solar irradiance and climate warming, indicating that variability in the solar irradiance was a potential driver of the climate and environmental changes in the NW Pacific during the EH. The low-productivity/cold climate CsS-EH-2 event in records of atmospheric $\Delta^{14} \mathrm{C}$ and the Greenland $\delta^{18} \mathrm{O}$ ice core was marked by sharp cooling at its onset and termination with some warming during the transition (Fig. 5). The CsS-EH-4 event shows a similar pattern in records of productivity stack and $\delta^{18} \mathrm{O}$ of the Greenland and Dongge cave $\mathrm{D} 4$, indicating fine structure of these cold events.

The influence of variations in solar output on hydrography of surface ocean in the subpolar N Atlantic during the Holocene was reported by Bond et al. (2001). The variability in subpolar N Atlantic ice drifting, recorded as the percentage of hematite-stained grains (Bond et al., 2001), though having lower time resolution and dating precision compared with production of the cosmogenic nuclides, is consistent with other centennial climate changes in the Northern Hemisphere during the EH (Fig. 5).

The high-resolution records of an alternation of the NW Pacific events with lower/higher productivity related to climate cooling/warming demonstrate that centennial-scale climate events during the EH were similar between the N Atlantic and NW Pacific, possibly because of the close linkages of sun, ocean and climate, consistent with earlier conclusions (Bond et al., 2001; Hong et al., 2009; Hu et al., 2003).

\subsection{Cross-correlation of the N Atlantic-NW Pacific climate variability}

Since N Atlantic-NW Pacific climate and hydrological inphase or out-of-phase linkages are still under debate, empirical data obtained from sediment cores off Kamchatka offer the provision for clarifying this issue at high resolution. Here we provide comparison of the productivity stack of core 41-2, responsible for NW Pacific environmental variability, and $\delta^{18} \mathrm{O}$ records of the NGRIP ice core, responsible for the Greenland/N Atlantic climate changes (Rasmussen et al., 2014). Cross correlation of these records using moving windows at 2000 years shows more significant synchronization (from -0.6 to -0.9 ) from 15.8 to $10.8 \mathrm{ka}$, confirming strong atmospheric teleconnections between the NW Pacific and the $\mathrm{N}$ Atlantic during this period (Fig. 6). Cross correlation during early (19-15.8 ka) and later periods (10.8-9 ka) indicates weak NW Pacific-N Atlantic linkages but does not support the out-of-phase hypothesis.

\section{Conclusions}

This study presents high-resolution records of productivity proxies (TOC, $\mathrm{CaCO}_{3}$, chlorin, color b*, Ba-bio, Br-bio and Si-bio), sediment lithological, and magnetic properties from two sediment cores, $41-2$ and $12 \mathrm{KL}$, taken from the NW Pacific. Results presented here reveal 16 centennial regional productivity events during the LGM-EH $(20-8 \mathrm{ka})$ in the NW Pacific. Four NW Pacific abrupt increased-productivity events are linked to CsIs during the LGM (20-17.8 ka), four during HE 1 (17.8-14.7 ka) and four during the B/A. An alternative occurrence of four centennial events with lower and higher productivity was established during the EH.

On the basis of the age models of cores 41-2 and 12KL, we suggest that NW Pacific centennial events of increased productivity occur synchronously with sub-interstadials of the EASM. These NW Pacific events and EASM subinterstadials are positively correlated with Greenland abrupt 
warming, indicating an atmospheric teleconnection between the NW Pacific and the N Atlantic during the LGM-HE 1$\mathrm{B} / \mathrm{A}$.

Remarkable similarity in the sequence of productivity events recorded in the NW Pacific with the EASM subinterstadials during the LGM-HE1 implies that SH is a strong driver. The comparison between our stacked productivity with the $\delta^{18} \mathrm{O}$ of the EPICA, NGRIP and EASM suggests that another mechanism associated with the temperature gradient in the Southern Hemisphere ("push effect") may relate to the EASM sub-interstadials and subsequent variability in productivity events in the NW Pacific on centennial timescales during the LGM-HE1.

During the B/A warming and resumption of the AMOC, synchronicity between the productivity events, EASM subinterstadials, and the $\delta^{18} \mathrm{O}$ and dust records in the NGRIP is consistent with enhancement of the "pull effect" on the monsoon's intensity, which implies a dominant control of atmospheric processes on the productivity and climate of the NW Pacific.

During the EH, the high-resolution records of an alternation of productivity events with lower/higher productivity related to climate cooling/warming reveal that centennial climate events were similar between the subpolar regions of the N Atlantic and NW Pacific and were controlled by mechanisms of sun-ocean-climate linkages.

In summary, the NW Pacific results presented here indicate a tight linkage and coherent pattern of centennial-millennialscale climate changes during the LGM-EH, which may serve as a template in high-resolution paleoceanography and sediment stratigraphy of the moderate-high latitudes in the NW Pacific.

Data availability. The associated data have been uploaded to the website of the V.I. Il'ichev Pacific Oceanological Institute, Far Eastern Branch of RAS: https://box.poi.dvo.ru/owncloud/index.php/s/ Sm1vqewyfnfu5XV.

Competing interests. The authors declare that they have no conflict of interest.

Acknowledgements. We are grateful to Ralf Tiedemann and Dirk Nürnberg (AWI, GEOMAR, Germany) for a long and fruitful cooperation, and for providing samples and the dataset of core $12 \mathrm{KL}$. We are indebted to John Southon (USA) for the AMS ${ }^{14} \mathrm{C}$ dating. We thank Selvaraj Kandasamy (Xiamen University) for correcting the paper. This research work was supported by the RFBR (Russian Fund of Basic Research), Russian projects 13-05-00296a, 16-55-53048 and 16-05-00127, Russian Federation budget (no. 01201363042), the International Cooperation Project of Global Change and Ocean-Atmosphere Interaction (GASIGEOGE-04), the National Natural Science Foundation of China (grant nos. 41476056, 41611130042 and U1606401) and international cooperative projects in polar regions (201613), as well as by Russia-Taiwan Research Cooperation projects (14-HHC-002 and 17-MHT-003).

Edited by: Erin McClymont

Reviewed by: two anonymous referees

\section{References}

Barron, J. A., Heusser, L., Herbert, T., and Lyle, M.: Highresolution climatic evolution of coastal northern California during the past 16,000 years, Paleoceanography, 18, 1020, https://doi.org/10.1029/2002PA000768, 2003.

Barron, J. A., Bukry, D., Dean, W. E., Addison, J. A., and Finney, B.: Paleoceanography of the Gulf of Alaska during the past 15,000 years: Results from diatoms, silicoflagellates, and geochemistry, Mar. Micropaleontol., 72, 176-195, https://doi.org/10.1016/j.marmicro.2009.04.006, 2009.

Berger, W. H., Smetacek, V. S., and Wefer, G.: Ocean Productivity and Paleoproductivity - An Overview, in: Productivity of the Ocean: Present and Past, John Wiley \& Sons Limited, Dahlem Konferenzen, 1-34, 1989.

Bezrukova, E. V., Tarasov, P. E., Solovieva, N., Krivonogov, S. K., and Riedel, F.: Last glacial-interglacial vegetation and environmental dynamics in southern Siberia: Chronology, forcing and feedbacks, Palaeogeogr. Palaeocl., 296, 185-198, https://doi.org/10.1016/j.palaeo.2010.07.020, 2010.

Björck, S., Walker, M. J. C., Cwynar, L. C., Johnsen, S., Knudsen, K.-L., Lowe, J. J., and Wohlfarth, B.: An event stratigraphy for the Last Termination in the North Atlantic region based on the Greenland ice-core record: a proposal by the INTIMATE group, J. Quaternary Sci., $\quad 13, \quad 283-292, \quad$ https://doi.org/10.1002/(SICI)10991417(199807/08)13:4<283::AID-JQS386>3.0.CO;2-A, 1998.

Bond, G. C., Kromer, B., Beer, J., Muscheler, R., Evans, M. N., Showers, W., Hoffmann, S., Lotti-Bond, R., Hajdas, I., and Bonani, G.: Persistent solar influence on North Atlantic climate during the Holocene, Science, 294, 2130-2136, https://doi.org/10.1126/science.1065680, 2001.

Caissie, B. E., Brigham-Grette, J., Lawrence, K. T., Herbert, T. D., and Cook, M. S.: Last Glacial Maximum to Holocene sea surface conditions at Umnak Plateau, Bering Sea, as inferred from diatom, alkenone, and stable isotope records, Paleoceanography, 25, PA1206, https://doi.org/10.1029/2008PA001671, 2010.

Channell, J. E. T., Xuan, C., and Hodell, D. A.: Stacking paleointensity and oxygen isotope data for the last 1.5 Myr (PISO-1500), Earth Planet. Sc. Lett., 283, 14-23, https://doi.org/10.1016/j.epsl.2009.03.012, 2009.

Chikamoto, M. O., Menviel, L., Abe-Ouchi, A., Ohgaito, R., Timmermann, A., Okazaki, Y., Harada, N., Oka, A., and Mouchet, A.: Variability in North Pacific intermediate and deep water ventilation during Heinrich events in two coupled climate models, Deep-Sea Res. Pt. II, 61-64, 114-126, https://doi.org/10.1016/j.dsr2.2011.12.002, 2012.

Dansgaard, W., Johnsen, S. J., Clausen, H. B., Dahl-Jensen, D., Gundestrup, N. S., Hammer, C. U., Hvidberg, C. S., Steffensen, J. P., Sveinbjörn, Jouzel, J., and Bond, G. C.: Evidence for general instability of past climate from a $250-\mathrm{kyr}$ ice-core record, Nature, 364, 218-220, https://doi.org/10.1038/364218a0, 1993. 
Dykoski, C. A., Edwards, R. L., Cheng, H., Yuan, D., Cai, Y., Zhang, M., Lin, Y., Qing, J., An, Z., and Revenaugh, J.: A highresolution, absolute-dated Holocene and deglacial Asian monsoon record from Dongge Cave, China, Earth Planet. Sc. Lett., 233, 71-86, https://doi.org/10.1016/j.epsl.2005.01.036, 2005.

Dymond, J., Suess, E., and Lyle, M.: Barium in Deep-Sea Sediment: A Geochemical Proxy for Paleoproductivity, Paleoceanography, 7, 163-181, https://doi.org/10.1029/92PA00181, 1992.

Enkin, R. J., Baker, J., Nourgaliev, D., Iassonov, P., and Hamilton, T. S.: Magnetic hysteresis parameters and Day plot analysis to characterize diagenetic alteration in gas hydrate-bearing sediments, J. Geophys. Res., 112, 1-13, https://doi.org/10.1029/2006JB004638, 2007.

EPICA Community Members: One-to-one coupling of glacial climate variability in Greenland and Antarctica, Nature, 444, 195198, https://doi.org/10.1038/nature05301, 2006.

Favorite, F., Dodimead, A. J., and Nasu, K.: Oceanography of the Subarctic Pacific region, 1960-1971, 187 pp., Int. North Pacific Fisheries Comm., Vancouver, B. C., 1976.

Fletcher, W. J., Sanchez Goñi, M. F., Allen, J. R. M., Cheddadi, R., Combourieu-Nebout, N., Huntley, B., Lawson, I., Londeix, L., Magri, D., Margari, V., Müller, U. C., Naughton, F., Novenko, E., Roucoux, K., and Tzedakis, P. C.: Millennial-scale variability during the last glacial in vegetation records from Europe, Quaternary Sci. Rev., 29, 2839-2864, https://doi.org/10.1016/j.quascirev.2009.11.015, 2010.

Galbraith, E. D., Jaccard, S. L., Pedersen, T. F., Sigman, D. M., Haug, G. H., Cook, M., Southon, J. R., and Francois, R.: Carbon dioxide release from the North Pacific abyss during the last deglaciation, Nature, 449, 890-893, https://doi.org/10.1038/nature06227, 2007.

Gebhardt, H., Sarnthein, M., Grootes, P. M., Kiefer, T., Kuehn, H., Schmieder, F., and Röhl, U.: Paleonutrient and productivity records from the subarctic North Pacific for Pleistocene glacial terminations I to V, Paleoceanography, 23, PA4212, https://doi.org/10.1029/2007PA001513, 2008.

Goldberg, E. D. and Arrhenius, G. O. S.: Chemistry of Pacific pelagic sediments, Geochim. Cosmochim. Ac., 13, 153-212, https://doi.org/10.1016/0016-7037(58)90046-2, 1958.

Goldberg, E. L., Gorbarenko, S. A., Shaporenko, A. D., Bosin, A. A., Leskov, V. Y., and Chebykin, E. P.: Instability of last glacial climate from SRXFA data for bottom sediments in the Okhotsk Sea, Nucl. Instruments Methods Phys. Res. Sect. A Accel. Spectrometers, Detect. Assoc. Equip., 543, 284-287, https://doi.org/10.1016/j.nima.2005.01.242, 2005.

Gorbarenko, S. A.: Stable Isotope and Lithologic Evidence of Late-Glacial and Holocene Oceanography of the Northwestern Pacific and Its Marginal Seas, Quaternary Res., 46, 230-250, https://doi.org/10.1006/qres.1996.0063, 1996.

Gorbarenko, S. A. and Goldberg, E. L.: Assessment of Variations of Primary Production in the Sea of Okhotsk, Bering Sea, and Northwestern Pacific over the Last Glaciation Maximum and Holocene, Dokl. Earth Sci., 405, 1380-1383, 2005.

Gorbarenko, S. A., Chekhovskaya, M. P., and Southon, J. R.: Detailed environmental changes of the Okhotsk Sea central part during last Glaciation Holocene, Oceanologia, 38, 305-308, 1998.

Gorbarenko, S. A., Leskov, V. Y., Artemova, A. V., Tiedemann, R., Biebow, N., and Nürnberg, D.: Ice Cover of the Sea of Okhotsk during the Last Glaciation and Holocene, Dokl. Earth Sci., 389, 208-211, 2003.

Gorbarenko, S. A., Southon, J. R. J., Keigwin, L. D., Cherepanova, M., and Gvozdeva, I. G.: Late Pleistocene-Holocene oceanographic variability in the Okhotsk Sea: geochemical, lithological and paleontological evidence, Palaeogeogr. Palaeocl., 209, 281301, https://doi.org/10.1016/j.palaeo.2004.02.013, 2004.

Gorbarenko, S. A., Basov, I. A., Chekhovskaya, M. P., Southon, J. R., Khusid, T. A. A., and Artemova, A. V.: Orbital and millennium scale environmental changes in the southern Bering Sea during the last glacial-Holocene: Geochemical and paleontological evidence, Deep-Sea Res. Pt. II, 52, 2174-2185, https://doi.org/10.1016/j.dsr2.2005.08.005, 2005.

Gorbarenko, S. A., Harada, N., Malakhov, M. I., Velivetskaya, T. A., Vasilenko, Y. P., Bosin, A. A., Derkachev, A. N., Goldberg, E. L., and Ignatiev, A. V.: Responses of the Okhotsk Sea environment and sedimentology to global climate changes at the orbital and millennial scale during the last $350 \mathrm{kyr}$, Deep-Sea Res. Pt. II, 6164, 73-84, https://doi.org/10.1016/j.dsr2.2011.05.016, 2012.

Harada, N.: MIRAI cruise report MR06-04 Leg 1 and 2, JAMSTEC, Yokosuka, available at: http://www.godac.jamstec.go.jp/darwin/ cruise/mirai/MR06-04_leg1/e (last access: 24 August 2017), 2006.

Harada, N., Sato, M., and Sakamoto, T.: Freshwater impacts recorded in tetraunsaturated alkenones and alkenone sea surface temperatures from the Okhotsk Sea across millennial-scale cycles, Paleoceanography, 23, PA3201, https://doi.org/10.1029/2006PA001410, 2008.

Harris, P. G., Zhao, M., Rosell-Melé, A., Tiedemann, R., Sarnthein, M., and Maxwell, J. R.: Chlorin accumulation rate as a proxy for Quaternary marine primary productivity, Nature, 383, 63-65, https://doi.org/10.1038/383063a0, 1996.

Hong, Y. T., Hong, B., Lin, Q. H., Shibata, Y., Zhu, Y. X., Leng, X. T., and Wang, Y.: Synchronous climate anomalies in the western North Pacific and North Atlantic regions during the last 14,000 years, Quaternary Sci. Rev., 28, 840-849, https://doi.org/10.1016/j.quascirev.2008.11.011, 2009.

Hu, F. S., Kaufman, D., Yoneji, S., Nelson, D., Shemesh, A., Huang, Y., Tian, J., Bond, G. C., Clegg, B., and Brown, T. A.: Cyclic variation and solar forcing of Holocene climate in the Alaskan subarctic, Science, 301, 1890-1893, https://doi.org/10.1126/science.1088568, 2003.

Jaccard, S. L., Galbraith, E. D., Sigman, D. M., and Haug, G. H.: A pervasive link between Antarctic ice core and subarctic Pacific sediment records over the past 800 kyrs, Quaternary Sci. Rev., 29, 206-212, https://doi.org/10.1016/j.quascirev.2009.10.007, 2010.

Jasonov, P. G., Nurgaliev, D. K., Burov, B. V., and Heller, F.: A modernized coercivity spectrometer, Geol. Carpath., 49, 2254 225, 1998.

Jin, L., Chen, F., Ganopolski, A., and Claussen, M.: Response of East Asian climate to Dansgaard/Oeschger and Heinrich events in a coupled model of intermediate complexity, J. Geophys. Res., 112, D06117, https://doi.org/10.1029/2006JD007316, 2007.

Johnsen, S. J., Clausen, H. B., Dansgaard, W., Fuhrer, K., Gundestrup, N., Hammer, C. U., Iversen, P., Jouzel, J., Stauffer, B., and Steffensen, J. P.: Irregular glacial interstadials recorded in a new Greenland ice core, Nature, 359, 311-313, https://doi.org/10.1038/359311a0, 1992. 
Keigwin, L. D.: Glacial-age hydrography of the far northwest Pacific Ocean, Paleoceanography, 13, 323-339, https://doi.org/10.1029/98PA00874, 1998.

Keigwin, L. D., Jones, G. A., and Froelich, P. N.: A 15,000 year paleoenvironmental record from Meiji Seamount, far northwestern Pacific, Earth Planet. Sc. Lett., 111, 425-440, https://doi.org/10.1016/0012-821X(92)90194-Z, 1992.

Kennett, J. P., Roark, E. B., Cannariato, K. G., Ingram, B. L., and Tada, R.: Latest quaternary paleoclimatic and radiocarbon chronology, Hole 1017E, Southern California margin, Proc. Ocean Drill. Progr., 167, 249-254, 2000.

Kiefer, T., Sarnthein, M., Erlenkeuser, H., Grootes, P. M., and Roberts, A. P.: North Pacific response to millennial-scale changes in ocean circulation over the last $60 \mathrm{kyr}$, Paleoceanography, 16, 179-189, https://doi.org/10.1029/2000PA000545, 2001.

Kienast, S. S. and McKay, J. L.: Sea surface temperature in the subartic Northeast Pacific reflect millennial-scale climate oscillations during the last $16 \mathrm{kyr}$, Geophys. Res. Lett., 28, 1563-1566, 2001.

Kim, S.-J., Khim, B.-K., Uchida, M., Itaki, T., and Tada, R.: Millennial-scale paleoceanographic events and implication for the intermediate-water ventilation in the northern slope area of the Bering Sea during the last 71 kyrs, Global Planet. Change, 79, 89-98, https://doi.org/10.1016/j.gloplacha.2011.08.004, 2011.

Kimura, N. and Wakatsuchi, M.: Processes controlling the advance and retreat of sea ice in the Sea of Okhotsk, J. Geophys. Res., 104, 11137, https://doi.org/10.1029/1999JC900004, 1999.

Lisitzin, A. P.: Sea-Ice and Iceberg Sedimentation in the Ocean, Springer, Berlin, Heidelberg, 2002.

Malakhov, M. I., Gorbarenko, S. A., Malakhova, G. Y., Harada, N., Vasilenko, Y. P., Bosin, A. A., Goldberg, E. L., and Derkachev, A. N.: Petromagnetic parameters of bottom sediments as indicators of the climatic and environmental changes in the central zone of the Sea of Okhotsk during the last $350 \mathrm{kyr}$, Russ. Geol. Geophys., 50, 973-982, https://doi.org/10.1016/j.rgg.2009.10.006, 2009.

Max, L., Riethdorf, J.-R., Tiedemann, R., Smirnova, M., Lembke-Jene, L., Fahl, K., Nürnberg, D., Matul, A. G., and Mollenhauer, G.: Sea surface temperature variability and sea-ice extent in the subarctic northwest Pacific during the past 15,000 years, Paleoceanography, 27, PA3213, https://doi.org/10.1029/2012PA002292, 2012.

Max, L., Lembke-Jene, L., Riethdorf, J.-R., Tiedemann, R., Nürnberg, D., Kühn, H., and Mackensen, A.: Pulses of enhanced North Pacific Intermediate Water ventilation from the Okhotsk Sea and Bering Sea during the last deglaciation, Clim. Past, 10, 591-605, https://doi.org/10.5194/cp-10-591-2014, 2014.

McManus, J., Berelson, W. M., Klinkhammer, G. P., Johnson, K. S., Coale, K. H., Anderson, R. F., Kumar, N., Burdige, D. J., Hammond, D. E., Brumsack, H.-J., McCorkle, D. C., and Rushdi, A.: Geochemistry of barium in marine sediments: implications for its use as a paleoproxy, Geochim. Cosmochim. Ac., 62, 34533473, https://doi.org/10.1016/S0016-7037(98)00248-8, 1998.

McManus, J. F., Francois, R., Gherardi, J.-M., Keigwin, L. D., and Brown-Leger, S.: Collapse and rapid resumption of Atlantic meridional circulation linked to deglacial climate changes, Nature, 428, 834-837, https://doi.org/10.1038/nature02494, 2004.

Nagashima, K., Tada, R., Tani, A., Sun, Y., Isozaki, Y., Toyoda, S., and Hasegawa, H.: Millennial-scale oscillations of the westerly jet path during the last glacial period, J. Asian Earth Sci., 40, 1214-1220, https://doi.org/10.1016/j.jseaes.2010.08.010, 2011.

Narita, H., Sato, M., Tsunogai, S., Murayama, M., Ikehara, M., Nakatsuka, T., Wakatsuchi, M., Harada, N., and Ujiié, Y.: Biogenic opal indicating less productive northwestern North Pacific during the glacial ages, Geophys. Res. Lett., 29, 22-1-22-4, https://doi.org/10.1029/2001GL014320, 2002.

Nilsson, T.: The Pleistocene; Geology and Life in the Quaternary Ice Age, D. Reidel, Dordrecht, 1983.

North Greenland Ice Core Project members: High-resolution record of Northern Hemisphere climate extending into the last interglacial period, Nature, 431, 147-151, https://doi.org/10.1038/nature02805, 2004.

Nürnberg, D. and Tiedemann, R.: Environmental change in the Sea of Okhotsk during the last 1.1 million years, Paleoceanography, 19, PA4011, https://doi.org/10.1029/2004PA001023, 2004.

Okazaki, Y., Timmermann, A., Menviel, L., Harada, N., Abe-Ouchi, A., Chikamoto, M. O., Mouchet, A., and Asahi, H.: Deepwater formation in the North Pacific during the Last Glacial Termination, Science, 329, 200-204, https://doi.org/10.1126/science.1190612, 2010.

Praetorius, S. K. and Mix, A. C.: Synchronization of North Pacific and Greenland climates preceded abrupt deglacial warming, Science, 345, 444-448, https://doi.org/10.1126/science.1252000, 2014.

Prahl, F. G., Muehlhausen, L. A., and Lyle, M.: An organic geochemical assessment of oceanographic conditions at Manop Site C over the past 26,000 years, Paleoceanography, 4, 495-510, https://doi.org/10.1029/PA004i005p00495, 1989.

Rasmussen, S. O., Bigler, M., Blockley, S. P., Blunier, T., Buchardt, S. L., Clausen, H. B., Cvijanovic, I., Dahl-Jensen, D., Johnsen, S. J., Fischer, H., Gkinis, V., Guillevic, M., Hoek, W. Z., Lowe, J. J., Pedro, J. B., Popp, T., Seierstad, I. K., Steffensen, J. P., Svensson, A. M., Vallelonga, P., Vinther, B. M., Walker, M. J. C., Wheatley, J. J., and Winstrup, M.: A stratigraphic framework for abrupt climatic changes during the Last Glacial period based on three synchronized Greenland ice-core records: refining and extending the INTIMATE event stratigraphy, Quaternary Sci. Rev., 106, 14-28, https://doi.org/10.1016/j.quascirev.2014.09.007, 2014.

Reimer, P. J., Baillie, M. G. L., Bard, E., Beck, J. W., Bertrand, C. J. H., Blackwell, P. G., Buck, C. E., Burr, G. S., Cutler, K. B., Damon, P. E., Edwards, R. L., Fairbanks, R. G., Friedrich, M., and Guilderson, T. P.: IntCal04 terrestrial radiocarbon age calibration, 0-26 cal kyr BP, Radiocarbon, 46, 1029-1058, 2004.

Reimer, P. J., Bard, E., Bayliss, A., Beck, J. W., Blackwell, P. G., Bronk Ramsey, C., Buck, C. E., Cheng, H., Edwards, R. L., Friedrich, M., Grootes, P. M., Guilderson, T. P., Haflidason, H., Hajdas, I., Hatte, C., Heaton, T. J., Hoffmann, D. L., Hogg, A. G., Hughen, K. A., Kaiser, K. F., Kromer, B., Manning, S. W., Niu, M., Reimer, R. W., Richards, D. A., Scott, E. M., Southon, J. R., Staff, R. A., Turney, C. S. M., and van der Plicht, J.: IntCal13 and Marine13 Radiocarbon Age Calibration Curves 0-50,000 Years cal BP, Radiocarbon, 55, 1869-1887, https://doi.org/10.2458/azu_js_rc.55.16947, 2013.

Riethdorf, J.-R., Nürnberg, D., Max, L., Tiedemann, R., Gorbarenko, S. A., and Malakhov, M. I.: Millennial-scale variability of marine productivity and terrigenous matter supply in the western Bering Sea over the past $180 \mathrm{kyr}$, Clim. Past, 9, 1345-1373, https://doi.org/10.5194/cp-9-1345-2013, 2013. 
Riethdorf, J.-R., Thibodeau, B., Ikehara, M., Nürnberg, D., Max, L., Tiedemann, R., Yokoyama, Y., Riethdorf, J.-R., Thibodeau, B., Ikehara, M., Nürnberg, D., Max, L., Tiedemann, R., and Yokoyama, Y.: Surface nitrate utilization in the Bering sea since $180 \mathrm{kABP}$ : Insight from sedimentary nitrogen isotopes, Deep-Sea Res. Pt., 125-126, 163-176, https://doi.org/10.1016/j.dsr2.2015.03.007, 2016.

Röhl, U. and Abrams, L. J.: High-resolution, downhole, and nondestructive core measurements from Sites 999 and 1001 in the Caribbean Sea: application to the Late Paleocene Thermal Maximum, in Proceedings of the Ocean Drilling Program, 165 Scientific Results, Vol. 165, 191-203, Ocean Drilling Program., 2000.

Rohling, E. J., Liu, Q. S., Roberts, a. P., Stanford, J. D., Rasmussen, S. O., Langen, P. L., and Siddall, M.: Controls on the East Asian monsoon during the last glacial cycle, based on comparison between Hulu Cave and polar ice-core records, Quaternary Sci. Rev., 28, 3291-3302, https://doi.org/10.1016/j.quascirev.2009.09.007, 2009.

Rossignol-Strick, M.: Mediterranean Quaternary sapropels, an immediate response of the African monsoon to variation of insolation, Palaeogeogr. Palaeocl., 49, 237-263, https://doi.org/10.1016/0031-0182(85)90056-2, 1985.

Rothwell, R. G.: The Smear Slide Method, in: Minerals and Mineraloids in Marine Sediments, 21-24, Springer Netherlands, Dordrecht, 1989.

Ruth, U., Bigler, M., Röthlisberger, R., Siggaard-Andersen, M.-L., Kipfstuhl, S., Goto-Azuma, K., Hansson, M. E., Johnsen, S. J., Lu, H., and Steffensen, J. P.: Ice core evidence for a very tight link between North Atlantic and east Asian glacial climate, Geophys. Res. Lett., 34, L03706, https://doi.org/10.1029/2006GL027876, 2007.

Sakamoto, T., Ikehara, M., Aoki, K., Iijima, K., Kimura, N., Nakatsuka, T., and Wakatsuchi, M.: Ice-rafted debris (IRD)based sea-ice expansion events during the past $100 \mathrm{kyrs}$ in the Okhotsk Sea, Deep-Sea Res. Pt. II, 52, 2275-2301, https://doi.org/10.1016/j.dsr2.2005.08.007, 2005.

Sarnthein, M., Kiefer, T., Grootes, P. M., Elderfield, H., and Erlenkeuser, H.: Warmings in the far northwestern Pacific promoted pre-Clovis immigration to America during Heinrich event $1, \mathrm{Ge}-$ ology, 34, 141-144, https://doi.org/10.1130/G22200.1, 2006.

Schlung, S. A., Christina Ravelo, A., Aiello, I. W., Andreasen, D. H., Cook, M. S., Drake, M., Dyez, K. A., Guilderson, T. P., LaRiviere, J. P., Stroynowski, Z., and Takahashi, K.: Millennial-scale climate change and intermediate water circulation in the Bering Sea from $90 \mathrm{ka}$ : A high-resolution record from IODP Site U1340, Paleoceanography, 28, 54-67, https://doi.org/10.1029/2012PA002365, 2013.

Seierstad, I. K., Abbott, P. M., Bigler, M., Blunier, T., Bourne, A. J., Brook, E. J., Buchardt, S. L., Buizert, C., Clausen, H. B., Cook, E., Dahl-Jensen, D., Davies, S. M., Guillevic, M., Johnsen, S. J., Pedersen, D. S., Popp, T. J., Rasmussen, S. O., Severinghaus, J. P., Svensson, A., and Vinther, B. M.: Consistently dated records from the Greenland GRIP, GISP2 and NGRIP ice cores for the past $104 \mathrm{ka}$ reveal regional millennial-scale $\delta^{18} \mathrm{O}$ gradients with possible Heinrich event imprint, Quaternary Sci. Rev., 106, 29 46, https://doi.org/10.1016/j.quascirev.2014.10.032, 2014.

Seki, O., Ishiwatari, R., and Matsumoto, K.: Millennial climate oscillations in NE Pacific surface waters over the last $82 \mathrm{kyr}$ : New evidence from alkenones, Geophys. Res. Lett., 29, 59-1-59-4, https://doi.org/10.1029/2002GL015200, 2002.

Seki, O., Ikehara, M., Kawamura, K., Nakatsuka, T., Ohnishi, K., Wakatsuchi, M., Narita, H., and Sakamoto, T.: Reconstruction of paleoproductivity in the Sea of Okhotsk over the last $30 \mathrm{kyr}$, Paleoceanography, 19, PA1016, https://doi.org/10.1029/2002PA000808, 2004.

Serno, S., Winckler, G., Anderson, R. F., Maier, E., Ren, H., Gersonde, R., and Haug, G. H.: Comparing dust flux records from the Subarctic North Pacific and Greenland: Implications for atmospheric transport to Greenland and for the application of dust as a chronostratigraphic tool, Paleoceanography, 30, 583-600, https://doi.org/10.1002/2014PA002748, 2015.

Siddall, M., Kaplan, M. R., Schaefer, J. M., Putnam, A., Kelly, M. A., and Goehring, B.: Changing influence of Antarctic and Greenlandic temperature records on sea-level over the last glacial cycle, Quaternary Sci. Rev., 29, 410-423, https://doi.org/10.1016/j.quascirev.2009.11.007, 2010.

Stuiver, M. and Reimer, P. J.: Extended ${ }^{14} \mathrm{C}$ Data Base and Revised Calib 3.0 ${ }^{14} \mathrm{C}$ Age Calibration Program, Radiocarbon, 35, 215 230, 1993.

Stuiver, M., Grootes, P. M., and Braziunas, T. F.: The GISP2 $\delta^{18} \mathrm{O}$ Climate Record of the Past 16,500 Years and the Role of the Sun, Ocean, and Volcanoes, Quaternary Res., 44, 341-354, https://doi.org/10.1006/qres.1995.1079, 1995.

Sun, Y., Clemens, S. C., Morrill, C., Lin, X., Wang, X., and An, Z.: Influence of Atlantic meridional overturning circulation on the East Asian winter monsoon, Nat. Geosci., 5, 46-49, https://doi.org/10.1038/ngeo1326, 2012.

Sung, M.-K., Kwon, W.-T., Baek, H.-J., Boo, K.-O., Lim, G.-H., and Kug, J.-S.: A possible impact of the North Atlantic Oscillation on the east Asian summer monsoon precipitation, Geophys. Res. Lett., 33, L21713, https://doi.org/10.1029/2006GL027253, 2006.

Tarasov, P. E., Bezrukova, E. V., and Krivonogov, S. K.: Late Glacial and Holocene changes in vegetation cover and climate in southern Siberia derived from a $15 \mathrm{kyr}$ long pollen record from Lake Kotokel, Clim. Past, 5, 285-295, https://doi.org/10.5194/cp-5285-2009, 2009.

Tauxe, L.: Sedimentary records of relative paleointenstiy of the geomagnetic field: theory and practice, Rev. Geophys., 31, 319-354, 1993.

Timmermann, A., Lorenz, S. J., An, S.-I., Clement, A., and Xie, S.-P.: The Effect of Orbital Forcing on the Mean Climate and Variability of the Tropical Pacific, J. Climate, 20, 4147-4159, https://doi.org/10.1175/JCLI4240.1, 2007.

Walker, M. J. C., Berkelhammer, M., Björck, S., Cwynar, L. C., Fisher, D. A., Long, A. J., Lowe, J. J., Newnham, R. M., Rasmussen, S. O., and Weiss, H.: Formal subdivision of the Holocene Series/Epoch: a Discussion Paper by a Working Group of INTIMATE (Integration of ice-core, marine and terrestrial records) and the Subcommission on Quaternary Stratigraphy (International Commission on Stratigraphy), J. Quaternary Sci., 27, 649-659, https://doi.org/10.1002/jqs.2565, 2012.

Wang, Y., Cheng, H., Edwards, R. L., An, Z., Wu, J., Shen, C.-C., and Dorale, J. A.: A high-resolution absolute-dated late Pleistocene Monsoon record from Hulu Cave, China, Science, 294, 2345-2348, https://doi.org/10.1126/science.1064618, 2001. 
Wang, Y., Cheng, H., Edwards, R. L., He, Y., Kong, X., An, Z., Wu, J., Kelly, M. J., Dykoski, C. A., and Li, X.: The Holocene Asian monsoon: links to solar changes and North Atlantic climate., Science, 308, 854-857, https://doi.org/10.1126/science.1106296, 2005.

Wang, Y., Cheng, H., Edwards, R. L., Kong, X., Shao, X., Chen, S., Wu, J., Jiang, X., Wang, X., and An, Z.: Millennial- and orbital-scale changes in the East Asian monsoon over the past 224,000 years, Nature, 451, 1090-1093, https://doi.org/10.1038/nature06692, 2008.

Wu, B. and Wang, J.: Winter Arctic Oscillation, Siberian High and East Asian Winter Monsoon, Geophys. Res. Lett., 29, 3-1-3-4, https://doi.org/10.1029/2002GL015373, 2002.

Xue, F., Wang, H., and He, J.: Interannual Variability of Mascarene High and Australian High and Their Influences on East Asian Summer Monsoon, J. Meteorol. Soc. Jpn., 82, 1173-1186, https://doi.org/10.2151/jmsj.2004.1173, 2004.

Yu, J., Anderson, R. F., Jin, Z., Rae, J. W. B., Opdyke, B. N., and Eggins, S. M.: Responses of the deep ocean carbonate system to carbon reorganization during the Last Glacial-interglacial cycle, Quaternary Sci. Rev., 76, 39-52, https://doi.org/10.1016/j.quascirev.2013.06.020, 2013.
Yu, Y., Yang, T., Li, J., Liu, J., An, C., Liu, X., Fan, Z., Lu, Z., Li, Y., and Su, X.: Millennial-scale Holocene climate variability in the NW China drylands and links to the tropical Pacific and the North Atlantic, Palaeogeogr. Palaeocl., 233, 149-162, https://doi.org/10.1016/j.palaeo.2005.09.008, 2006.

Yuan, D., Cheng, H., Edwards, R. L., Dykoski, C. A., Kelly, M. J., Zhang, M., Qing, J., Lin, Y., Wang, Y., Wu, J., Dorale, J. A., An, Z., and Cai, Y.: Timing, duration, and transitions of the last interglacial Asian monsoon, Science, 304, 575-578, https://doi.org/10.1126/science.1091220, 2004.

Zijderveld, J. D. A.: A. C. demagnetization of rocks: analysis of results, in: Methods in Palaeomagnetism, edited by: Collinson, D. W., Creer, K. M., and Runcorn, S. K., 254-286, Elsevier, New York, 1964. 